\title{
Modelling Volatility Spillovers for Bio-ethanol, Sugarcane and Corn Spot and Futures Prices
}

Complutense

de Análisis

Económico

\author{
Chia-Lin Chang \\ Department of Applied EconomicsDepartment of Finance \\ National Chung Hsing University Taichung, Taiwan
}

\section{Michael McAleer}

Department of Quantitative Finance National Tsing Hua University, Taiwan And Econometric Institute, Erasmus School of Economics

Erasmus University Rotterdam and Department of Quantitative Economics

Complutense University of Madrid, Spain

And Institute of Advanced Sciences Yokohama National University, Japan

\section{Yu-Ann Wang}

Department of Applied Economics National Chung Hsing University

Taichung, Taiwan

\begin{abstract}
The recent and rapidly growing interest in biofuel as a green energy source has raised concerns about its impact on the prices, returns and volatility of related agricultural commodities. Analyzing the spillover effects on agricultural commodities and biofuel helps commodity suppliers hedge their portfolios, and manage the risk and co-risk of their biofuel and agricultural commodities. There have been many papers concerned with analyzing crude oil and agricultural commodities separately. The purpose of this paper is to examine the volatility spillovers for spot and futures returns on bioethanol and related agricultural commodities, specifically corn and sugarcane. The diagonal BEKK model is used as it is the only multivariate conditional volatility model with well-established regularity conditions and known asymptotic properties. The daily data used are from 31 October 2005 to 14 January 2015. The empirical results show that, in 2 of 6 cases for the spot market, there were significant negative co-volatility spillover effects: specifically, corn on subsequent sugarcane co-volatility with corn, and sugarcane on subsequent corn co-volatility with sugarcane. In the other 4 cases, there are no significant co-volatility spillover effects. There are significant positive co-volatility spillover effects in all 6 cases, namely between corn and sugarcane, corn and ethanol, and sugarcane and ethanol, and vice-versa, for each of the three pairs of commodities. It is clear that the futures prices of bio-ethanol and the two agricultural commodities, corn and sugarcane, have stronger co-volatility spillovers than their spot price counterparts. These empirical results suggest that the bio-ethanol and agricultural commodities should be considered as viable futures products in financial portfolios for risk management.
\end{abstract}

Keywords Biofuel, spot prices, futures prices, returns, volatility, risk, co-risk, bio-ethanol, corn, sugarcane, diagonal BEKK model, co-volatility spillover effects, hedging, risk management.

JEL Classification C32, C58, G13, G15, Q14, Q42.

\section{Working Paper no 1704}

December, 2016

UNIVERSIDAD

COMPLUTENSE

MADRID

ISSN: 2341-2356 


\title{
Modelling Volatility Spillovers for Bio-ethanol,
}

\section{Sugarcane and Corn Spot and Futures Prices*}

\author{
Chia-Lin Chang \\ Department of Applied Economics \\ Department of Finance \\ National Chung Hsing University \\ Taichung, Taiwan \\ Michael McAleer** \\ Department of Quantitative Finance \\ National Tsing Hua University, Taiwan \\ and \\ Econometric Institute, Erasmus School of Economics \\ Erasmus University Rotterdam \\ and \\ Department of Quantitative Economics \\ Complutense University of Madrid, Spain \\ And \\ Institute of Advanced Sciences \\ Yokohama National University, Japan \\ Yu-Ann Wang \\ Department of Applied Economics \\ National Chung Hsing University \\ Taichung, Taiwan
}

Revised: December 2016

* The authors are most grateful to the Editor and three reviewers for detailed and very helpful comments and suggestions. For financial support, the first author wishes to thank the National Science Council, Ministry of Science and Technology (MOST), Taiwan, and the second author is grateful to the National Science Council, Ministry of Science and Technology (MOST), Taiwan and the Australian Research Council.

** Corresponding author: michael.mcaleer@gmail.com 


\begin{abstract}
The recent and rapidly growing interest in biofuel as a green energy source has raised concerns about its impact on the prices, returns and volatility of related agricultural commodities. Analyzing the spillover effects on agricultural commodities and biofuel helps commodity suppliers hedge their portfolios, and manage the risk and co-risk of their biofuel and agricultural commodities. There have been many papers concerned with analyzing crude oil and agricultural commodities separately. The purpose of this paper is to examine the volatility spillovers for spot and futures returns on bio-ethanol and related agricultural commodities, specifically corn and sugarcane. The diagonal BEKK model is used as it is the only multivariate conditional volatility model with well-established regularity conditions and known asymptotic properties. The daily data used are from 31 October 2005 to 14 January 2015. The empirical results show that, in 2 of 6 cases for the spot market, there were significant negative co-volatility spillover effects: specifically, corn on subsequent sugarcane co-volatility with corn, and sugarcane on subsequent corn co-volatility with sugarcane. In the other 4 cases, there are no significant co-volatility spillover effects. There are significant positive co-volatility spillover effects in all 6 cases, namely between corn and sugarcane, corn and ethanol, and sugarcane and ethanol, and vice-versa, for each of the three pairs of commodities. It is clear that the futures prices of bio-ethanol and the two agricultural commodities, corn and sugarcane, have stronger co-volatility spillovers than their spot price counterparts. These empirical results suggest that the bio-ethanol and agricultural commodities should be considered as viable futures products in financial portfolios for risk management.
\end{abstract}

Keywords: Biofuel, spot prices, futures prices, returns, volatility, risk, co-risk, bio-ethanol, corn, sugarcane, diagonal BEKK model, co-volatility spillover effects, hedging, risk management.

JEL: C32, C58, G13, G15, Q14, Q42. 


\section{Introduction}

\subsection{Discussion}

Following the Industrial Revolution, as industries rapidly developed all over the world, energy resources began to be used in increasingly large amounts, and oil stocks gradually declined. As the usage and exploitation of the world's oil accelerated, the U.S. Energy Information Administration (EIA) (2014) ("Biofuels Production Drives Growth in Overall Biomass Energy Use over Past Decade," Washington, DC) stated that the supply of oil was insufficient to meet demand, and because of speculation and the need to tap into oil reserves, the price of oil became increasingly unstable.

During the First World War, due to the shortage of oil, motor vehicles began to use a mixture of ethanol and gasoline as fuel. As the world subsequently experienced a succession of oil crises, there were dramatic fluctuations in oil prices. For example, in 1973 due to the war in the Middle East, the Organization of the Petroleum Exporting Countries (OPEC) imposed an embargo on exports of oil which led to the First Oil Crisis, during which time the price of crude oil rose from less than US\$3 per barrel to nearly US\$12. In addition, following the outbreak of the Iran-Iraq war in 1979, there was a significant decline in the amount of oil produced, which resulted in the Second Oil Crisis, during which oil prices rose from US\$15 a barrel to nearly US\$39.

Furthermore, excessive use of fossil energy also contributed to global warming and greenhouse gas emissions, with the result that a meeting of the United Nations Framework Convention on Climate Change was convened in Kyoto, Japan in December 1997, at which member countries unanimously agreed to draw up the "Kyoto Protocol" 
(United Nations Framework Convention on Climate Change (2015)

(http://unfccc.int/kyoto_protocol/items/2830.php). Each country was invited to sign the Protocol between 16 March 1998 and 15 March 1999 in order that, through the implementation of this Agreement, each country's emissions of greenhouse gases would be reduced. Many countries began to implement policies in response, with the use of biomass energy being an important development.

During the first commitment period, 37 industrialized countries and the European Community committed to reduce GHG emissions to an average of five percent against 1990 levels. The second period, as the report from United Nations Framework Convention on Climate Change (UNFCCC) in 2015, the Paris Agreement committed to reduce GHG emissions by at least 18 percent below 1990 levels in the eight-year period from 2013 to 2020.

According to EIA data, between 2002 and 2013, biomass energy production grew by more than $60 \%$ in the USA, with the main source of this growth being the production of ethanol. Some $60 \%$ of the biomass energy crops grown were able to be converted from the original raw materials into biomass fuels. Total energy production in the USA shows that, from 2000 to 2015, there were increases in natural gas, crude oil, renewables, and natural gas plant liquids, decreases in coal, and little change in nuclear (upper figure in Figure 1). Currently most of this biomass energy is blended with gasoline or diesel and used as fuel in motor vehicles, with substantial increases in inputs to ethanol from 2002 to 2013 (lower figure in Figure 1). 


\section{[Insert Figure 1 here]}

This paper broadly divides biomass energy according to how it is used after production into two categories, namely bio-ethanol and bio-diesel. Bio-ethanol can be blended with gasoline to be used as fuel, and its main sources are corn, cane sugar and sugar beet. Switchgrass is an expanding source of green fuel as an alternative to gasoline, but its financial characteristics have yet to be analysed empirically, primarily through lack of financial data.

Co-products are supposed to be credited with the area of cropland required to produce the amount of feed they substitute. If co-products are taken into account, the net use of feed stocks declines. By adding co-products substituted for grains and oilseeds, the land required for cultivation of feed stocks declines from about $2 \%$ to $1.5 \%$ net land requirement of the global crop area. Moreover, it is important to include the co-products in GHG assessment, because of their potential impact on overall emissions (for further details, see [1] Popp et al. (2014), [2] Popp et al. (2016)).

Bio-diesel can be blended with diesel fuel, and its main sources are soybeans, palm oil and rapeseed. The USA mainly produces corn and soybeans, while Brazil mainly produces sugar cane, corn and soybeans. The rapeseed used in the manufacture of bio-diesel is mostly grown in Europe, while South-East Asia mainly produces palm oil. From the countries in which these crops are produced, we can see the countries in which the major bio-fuels are manufactured. The USA and Brazil mainly manufacture bio-ethanol, while Europe and South-East Asia concentrate on bio-diesel. 
In addition to the agricultural products used in the past to manufacture bio-fuels, in recent years many scholars have begun to study the use of algae as a biomass energy raw material. Different kinds of algae can be used for different purposes. The polysaccharides found in large seaweeds, such as asparagus, ulva and sargassum, can be used to refine ethanol, and micro-algae, such as green algae and diatoms, which are higher in fats than other energy crops, can also be used as raw materials for bio-diesel (see Figure 2).

\section{[Insert Figure 2 here]}

Corn production plays a major role in the economy of the USA, which is one of the world's corn leaders with 96,000,000 acres (39,000,000 ha) of land reserved for corn production. Corn growth is dominated by west-north central Iowa and east-central Illinois. The USA is ranked first in the world in corn production, and approximately $13 \%$ of its annual yield is exported (http://www.grains.org/buyingselling/corn). The total production of corn in the USA for 2013-14 is reported to be 13.016 billion bushels, of which the major use is for manufacture of ethanol and its co-product (Distillers' Dried Grains with Solubles), accounting for 37\% (27\% + 10\%), or 4,845 million bushels $(3,552+1,293)$ ("Production and Use", Iowa Corn organization, retrieved 6 March 2014).

On the basis of the sourced evidence above, although the USA is the major producer of corn worldwide, about $50 \%$ of the corn produced is used as feed, with less 
than $10 \%$ being used as food for human consumption. For this reason, rising corn prices have caused the cost of feeding livestock to increase, with the result that budgets for the costs of technology have been impacted (the Renewable Fuels Association (RFA) (2014) (“Ethanol Facts: Agriculture,” Washington, DC), the ethanol industry’s lobby group, claims that ethanol production increases the price of corn by increasing demand).

In addition, impacted by the increased production of corn alcohol, many regions have begun to plant bean crops used as biofuels, hence the yield and price volatility of corn have caused the prices of other crops to become increasingly unstable ([3] Wisner, 2008; [4] Texas Comptroller of Public Accounts (2008)).

Almost all US production of ethanol uses corn as a feedstock. Even with the decline in US ethanol production, demand for corn to produce ethanol continues to have a strong presence in the sector, and is expected to account for over one-third of total US corn use throughout 2015-2025. By 2025, 22\% of global sugarcane and $10-11 \%$ of global coarse grains production is expected to be used to produce ethanol (see OECD/FAO (2016): OECD-FAO Agricultural Outlook 2016-2025, OECD Publishing, Paris, http://dx.doi.org/10.1787/agr_outlook-2016-en).

Feedstock use is related to animal feed produced from the ethanol industry, as well as affecting the net feedstock use for bioethanol production. One-third of each bushel of grain that enters the ethanol process is enhanced and is returned to the animal feed market, most often in the form of distillers grains, corn gluten feed, and corn gluten meal. Ethanol producers make both fuel and feed. Only the starch in the grain feedstock is converted 
to ethanol, while $100 \%$ of protein, fat, and fiber remain available to the feed market in the form of distillers grains or other co-products. By economically displacing traditional feed ingredients, ethanol co-products effectively reduce the livestock and poultry industry’s demand for maize and protein meal.

Growth in biofuel production has been accompanied by increased output of animal feed co-products from common biofuel processes The output of feed co-products is relatively high in the USA and the EU due to the large share of grains used in ethanol production with high feed yields, but is low in Brazil where ethanol production is dominated by sugarcane, which generates no feed co-products. The return of co-products to the feed market also has agricultural land use implications. At least one-third of every hectare "dedicated" to ethanol production should actually be characterized as producing feed, not fuel. The ethanol industry in the USA and EU produces an estimated 43 million metric tonnes of feed, including distillers' grains (90\%), and gluten feed and gluten meal.

Furthermore, using grain for ethanol has absolutely no impact on global protein supplies. In the EU, the required feedstock for bioethanol production is estimated at 10 million metric tonnes of cereals and 11 million metric tonnes of sugar beets, accounting for about 3\% of total EU cereal production and 9\% of total sugar beet production. In 2014, around 3.3 million tonnes of highly valuable animal feed (DDG, wheat gluten and yeast concentrates) was produced in the EU, which displaced nearly $10 \%$ of soybean and soybean meal imports by volume. Reducing imports of animal feed improves environmental footprint in the EU, and helps reduce land conversion and GHG 
emissions resulting from agricultural land use outside of Europe. For further details, see [5] PURE (2015), [6] Wisner (2015), and [7] RFS (2016).

According to the most recent research report prepared by the Renewable Fuels Association (RFA) in 2014, the increased prices of corn have compensated farm production costs, which has resulted in the federal government reducing its related subsidies. However, the report also points out that the corn used to produce ethanol and the sweet corn needed to supply food for human consumption are different, so that the production of bio-ethanol will not crowd out the quantity of food produced, and will not conflict with food security. Regardless of whether traditional energy crops constitute a threat to either food or land, with the development of biomass energy, in the future more diversified production methods are bound to develop, and new crops, some of which have been mentioned above, will be developed to produce bio-fuels.

Economic models show that bio-fuel use can result in higher crop prices, though the range of estimates in the literature is wide. Projections for the effect of bio-fuels on corn prices in 2015 range from 5\% to 53\% increases ([8] Zhang et al., 2013). The possible impact of developed countries' bio-fuels policies on global food prices became a significant concern in 2007 when global grain prices reached historic heights. Some experts (for example, [9] De Gorter et al. (2013a), [10] De Gorter et al. (2013b)) associated the unprecedented price spikes in food grain and oilseed with these countries’ bio-fuels policies. Most experts now agree that these policies are unlikely to have been the main culprit, although they may have been a factor emphasizing that bio-fuel policy is only responsible for part of the price increases in food grain commodities that is due 
to bio-fuels ([11] Durham et al., 2012).

Figure 3 shows that from 1980 to 2012, the trends in the proportion of corn used to produce bio-ethanol and corn prices, as the quantity of ethanol produced has increased steadily from 1996 to 2012, corn prices have also rapidly increased. US corn prices increased rapidly from 2005 to 2008, fell from 2008 to 2010, and then increased again until 2012, and fell through to 2015 (see Figure 4).

Figure 4 shows that from 1991 to 2012 the prices of ethanol-related agricultural products, such as corn and sugar cane have, for the most part, remained highly correlated. Corn prices have fallen steadily since 2012 through to 2015, while sugar cane prices fell from 2011 to 2013, and increased slightly in 2014. Recent stock market data show that bio-ethanol futures have continued to rise for much of 2016 through to December, though corn and sugar cane futures prices have fluctuated considerably, first rising for much of 2016, then falling in December.

\section{[Insert Figures 3-4 here]}

In order to manage the environment, at a sustainable level, large numbers of countries around the world are actively promoting the use of biomass energy, and the development of biomass energy is becoming increasingly popular. The primary crops used to produce biomass energy crops are corn and sugarcane, which are mostly used in the production of ethanol, while the main crops used in the production of diesel are beans and rapeseed. In both the spot and futures markets, the price volatility of a target 
crop used in the production of any kind of biomass energy is likely to increase the volatility in the prices of products involving other crops.

Crop producers may, by means of the price transmission of biomass energy and agricultural crops, as well as the direction in which the returns spillover effects are transmitted, improve the risk management of their portfolios. At the same time, through the risk spillover effects between different agricultural products and biofuels, that is, through the interactions in terms of the fluctuations in risk between different target crops, the volatility and risk of future losses can be reduced.

The concept of risk was proposed as early as 1895 by the American scholar John Haynes (1895) (“Risk as an Economic Factor,” Quarterly Journal of Economics, 9(4), 409-449), who classified and analyzed different types of risk. Spillover risk, also called transmission risk, refers to a situation that occurs in the short term. When a commodity experiences shocks, resulting in the fluctuations in the combined returns on products changing in either the same or opposite direction, investors can use the positive and negative relationships in the observed risk spillover effects to determine the direction of the impact of the returns between the different commodities. Thus, they can examine the increases or decreases in the overall risk of their portfolio of commodities. It can then be decided whether the different products can serve as assets within the investment portfolio in order to reduce the portfolio risk. For this reason, producers and managers of agricultural crops need to understand the price volatility of renewable energy crop products and the risk spillover effects of biomass energy, and thereby pursue an effective risk management strategy. 
Numerous papers in financial econometrics have proposed univariate conditional risk volatility models, such as the ARCH model of [12] Engle (1982), and GARCH model of [13] Bollerslev (1986), from which related conditional heteroskedastic models that capture the volatility of asset returns have been subsequently derived, such as the threshold TGARCH (or GJR) and EGARCH models ([14] Glosten et al, 1993; [15] McAleer et al, 2008; [16] McAleer, 2014; [17] McAleer and Hafner, 2014; [18] Martinet and McAleer, 2015; [19] Nelson, 1990; [20] Nelson, 1991; [21] Tsay, 1987).

Using univariate conditional volatility models, [22] Lence and Hayes (2002) examined crude oil, bio-fuel and energy policy, [23] Jin and Frechette (2004) used long memory models, and [24] Egelkraut et al. (2007) examined spillovers between spot and derivatives returns (although this can be problematic using univariate models as estimation is generally not efficient). There seems to have been little or no analysis of asymmetry or leverage in differentiating the effects of positive and negative shocks of equal magnitude on subsequent volatility.

However, individually measuring the risk for futures products in the market cannot clarify the interdependence between products and their related strengths in current international markets. Therefore, financial econometricians have developed different multivariate risk volatility models, such as the BEKK ([25] Engle and Kroner, 1995), DCC ([26] Engle, 2002), VARMA-GARCH ([27] Ling and McAleer, 2003), and VARMA-AGARCH ([28] McAleer et al. (2009) models, in which they discuss the risks transmitted between different assets, also referred to as the risk spillover effects.

In recent years, econometricians have gone further to discuss the lack of different 
statistical properties in multivariate risk volatility models, in the hope that they can more accurately capture the risk transmission effects among assets ([29] Bollerslev, 1990; [30] Bollerslev et al., 1988; [26] Engle, 2002; [31] Hafner and McAleer, 2014; [32] Jeantheau, 1998; [27] Ling and McAleer, 2003; [28] McAleer et al., 2009; [33] Tse and Tsui, 2002). Risk transmission is crucial is selecting suitable hedging instruments, in which negative covariances and correlations among financial returns are essential for insuring large losses in one financial asset are mitigated by positive returns in the hedging instrument.

Volatility spillovers using multivariate models have been considered by [34] Cesar and Marco (2012) and [35] Sendhil et al. (2013), while the BEKK model was used in [36] Trujillo-Barrera et al. (2012), the DCC model was estimated in [37] Cabrera and Schulz (2013), and the CCC, VARMA-GARCH, DCC and BEKK models were analyzed for crude oil spot and futures returns in [38] Chang et al. (2011).

Most previous studies on biomass energy have concentrated on researching the markets for bio-diesel crops, or on discussing the spillover effects among the food crop markets. Relatively few studies have focused on discussing bio-ethanol and the risk transmitted among related crops. In discussing the development of biomass energy, bio-ethanol and bio-diesel both have very important roles to play.

This paper focuses on bio-ethanol and the relevant agricultural products used in the production of bio-ethanol, and will analyze the risk spillover effects for the spot and futures returns on bio-ethanol, corn and sugar cane, so that the results might serve as a useful reference for policymakers, market investors and crop producers in the optimal 
management of risk.

The remainder of the paper is as follows. The literature on price transmission and volatility risk spillovers is reviewed in Section 2. In Section 3, we introduce the model specifications. A description of the sample and variables follows in Section 4, followed by the empirical results in Section 5. Some concluding remarks are given in Section 6 .

\subsection{Literature on Price Transmission and Risk Spillovers}

Past studies on the price transmission of agricultural crops have by and large, in accordance with the efficient markets hypothesis, discussed price transmission and price discovery. [39] Revoredo-Giha and Zuppiroli (2012) discussed the price efficiency in the European and US wheat futures markets, the London International Financial Futures and Options Exchange (LIFFE), the Marché à Terme International de France (MATIF), and the Chicago Mercantile Exchange Group (CBOT). They also calculated wheat futures and their corresponding wheat spot market prices, as well as the hedge ratios for East Anglia (UK), Rouen (France), Bologna (Italy) and Chicago (USA). The authors discovered that the MATIF market was more efficient than the other two futures markets. At the same time, regardless of whether the European or US markets were considered, wheat futures and spot prices were all significantly correlated, indicating that hedging efficiency existed in both the US and European markets.

[35] Sendhil et al. (2013) studied different futures contracts for wheat, chickpea, corn and barley in Indian markets, and examined whether price transmission and price 
disclosure existed among spot agricultural markets, using VECM and SUM to measure the price transmission and disclosure effects, respectively. From the results of the VECM, they found that the speeds of adjustment of the spot prices of chickpea and wheat were more rapid than those of the corresponding futures prices, whereas the speed of adjustment of the futures prices for corn was more rapid than that for the corresponding spot prices. The results of SUM indicated that there existed a price disclosure effect in both the spot and futures prices of corn and wheat, and that this price disclosure effect was more significant than in the markets for chickpea and wheat.

In addition to examining the price transmission relationships among agricultural products, [40] Chang et al. (2012) used the M-TAR (Momentum-Threshold Autoregressive) model and VECM to analyze the price transmission effects for bio-energy in different areas, as well as the speed of the price adjustment of three kinds of energy crops, namely corn, soybeans and sugar, and the price transmission effects between biomass energy and energy crops. It was found that bio-ethanol exhibited different speeds of price adjustment in different regions, implying that there exist opportunities to engage in arbitrage and price hedging. The price adjustment factor in relation to corn was the most significant, while the price adjustment factor in relation to sugar was the weakest. Bio-ethanol futures and agricultural products, due to their different speeds of price adjustment, could be used as a hedge against prices in food commodity markets.

A number of related studies in the literature that used the VECM to measure the price transmission effects between energy products and agricultural crops also found 
evidence of the existence of a price transmission relationship (see, among others, [37] Trujillo-Barrera et al., 2012; [37] Cabrera and Schulz, 2013; [41] Zhang et al., 2009; [42] Zhang et al., 2014).

[43] Zhao and Goodwin (2011) used [44] Black’s (1976) model to calculate the implied risk for corn and soybeans, and the VAR model to analyze the implied risk transmission relationship between corn and soybeans. Their results indicated that there was a risk spillover effect between corn and soybeans, but not the reverse. In addition, the authors used the threshold model to analyze the risk spillover effects between different time periods and found that, when the risk volatility of soybeans was high, soybeans exhibited a risk spillover effect in relation to corn; when the risk volatility of corn was high, soybeans exhibited a positive risk transmission relationship with corn; and when the risk volatility of corn was low, this risk transmission exhibited a negative relationship. The authors also compared the risk spillover effects estimated with the BEKK model. The results indicated that corn exhibited a risk spillover effect in relation to soybeans, and that the risk spillover effect for soybeans in relation to corn was significant.

[45] Nazlioglu et al. (2013) used the causality in variance (technically, causality for conditional volatility) approach proposed by [46] Hafner and Herwartz (2006) (see also [47] Chang and McAleer, 2016)) to analyze the spot price risk spillover effects between crude oil and corn, sugar, soybeans and wheat, both before and after the food price crisis of 2005. Their results indicated that prior to the outbreak of the food price crisis, only wheat exhibited a significant risk spillover effect in relation to crude oil, 
there being no such effect for the other crops. Moreover, there was no evidence of a risk spillover effect for petroleum in relation to these four agricultural crops.

However, after the food crisis occurred, apart from in the case of petroleum in relation to sugar, there was evidence of a significant risk transmission effect for petroleum in relation to all other products. As the volatility of petroleum prices became more pronounced, which led more countries to develop biomass energy products as alternatives to standard energy sources, the price volatilities of related agricultural products became higher than they had been in the past. Moreover, the prices of these products over time became more highly correlated with the price of petroleum. Previous studies that have discussed the risk spillover effects among markets for bio-ethanol, fossil fuels and agricultural products are mostly concentrated on the USA, Brazil and Europe (see, among others, [48] Serra, 2011; [49] Serra, 2012; [50] Serra et al., 2011; [51] Serra and Gil 2013).

Multivariate GARCH models used to measure the risk transmission or risk spillover effects between different commodities may be divided into two types. The first approach uses conditional covariances to explain the risk spillover effects between different commodities, such as the VECH and BEKK models. A second approach uses conditional correlations to analyze the correlations in the fluctuations between different commodities, such as the CCC ([29] Bollerslev, 1990) and DCC ([26] Engle, 2002) models. Regardless of whether the focus of the research is on futures and spot markets for agricultural products, between different agricultural products, or between energy and agricultural products, these models are very important when it comes to examining the 
roles played by risk transmission effects in reducing portfolio risk. The following gives a brief review.

[37] Trujillo-Barrera et al. (2012) used the Full BEKK model, that is, with no restrictions on the parameters in the conditional covariance matrix, to analyze the risk spillover effects for US crude oil, bio-ethanol and corn futures, and to measure the intensity of the risk transmission of crude oil futures prices on corn and bio-ethanol. The empirical results indicated that corn had a significant risk spillover effect on bio-ethanol, but not the reverse. There was a relatively high degree of intensity in terms of the spillover effects of crude oil on bio-ethanol.

[41] Zhang et al. (2009) also used the Full BEKK model to analyze the risk spillover effects between ethanol and agricultural products (namely, corn and soybeans), but the analysis was divided into two different periods, namely the early ethanol development period (1989-1999) and the later period (2000-2007). The results indicated that no significant risk transmission relationship was found to exist between ethanol and corn and soybeans in the development period. It was only in the late ethanol development period that there was evidence of a risk spillover effect from soybeans to ethanol.

[37] Cabrera and Schulz (2013) used the GARCH and DCC multivariate volatility model to analyze the risk spillover effects among crude oil, bio-diesel and rapeseed. The empirical results showed that there was a significant risk spillover effect between crude oil and rapeseed, but the risk spillover effect between bio-diesel and rapeseed was not significant. The authors argued that crude oil and rapeseed were globally traded 
commodities, whereas trade in bio-diesel tended to be limited to the European region. Therefore, there was no clear evidence of risk spillover effects between bio-diesel and the other two commodities.

[38] Chang et al. (2011) analyzed the risk transmission effects based on spot and futures market data for the two major crude oil markets, namely Brent and WTI. They compared the CCC, VARMA-GARCH, DCC, Full BEKK and Diagonal BEKK models, and found that, regardless of which model was used, the holding ratios for Brent crude oil futures always needed to be greater than the corresponding ratios in the spot market. However, in the WTI crude oil market, the results of the CCC and VARMA-GARCH models indicated that the spot market holding ratios needed to be greater than the corresponding ratios in the futures market.

In contrast, when the dynamic DCC and BEKK models were used, it was found that the spot market holding ratios should be larger than those in the futures market. In addition, by using hedging effectiveness to select the best model, the results indicated that the Diagonal BEKK model had the best hedging effectiveness, and was the best model used to calculate the asset portfolio. However, the BEKK model had the lowest hedging effectiveness value, and was therefore the least suitable model.

\section{Material and Methods}

\subsection{Model Specifications}


Despite the empirical applications of a wide range of conditional volatility models in numerous papers in empirical finance, there are theoretical problems associated with virtually all of them. The CCC, VARMA-GARCH, and its asymmetric counterpart, VARMA-AGARCH, models have static conditional covariances and correlations, which means that accommodating volatility spillovers is not possible. Apart from the diagonal version, the multivariate BEKK model of conditional covariances has been shown to have no regularity conditions, and hence no statistical properties (see [15] McAleer et al. (2008) and the discussion below for further details). Therefore, spillovers can be considered only for the special case of diagonal BEKK. The multivariate DCC model of (purported) conditional correlations has been shown to have no regularity conditions, and hence no statistical properties (see [31] Hafner and McAleer (2014) for further details).

The analysis of univariate and multivariate conditional volatility models below is a summary of what has been presented in the literature (see, for example, [52] Caporin and McAleer (2008), [53] Caporin and McAleer (2012)), although the comprehensive discussion of the full and diagonal BEKK models is not available in any published source. The first step in estimating multivariate models is to obtain the standardized residuals from the conditional mean returns shocks. For this reason, the most widely-used univariate conditional volatility model, namely GARCH, will be presented briefly, followed by the two most widely estimated multivariate conditional covariance models, namely the diagonal and full BEKK models. 


\subsubsection{Univariate Conditional Volatility}

Consider the conditional mean of financial returns, as follows:

$$
y_{t}=E\left(y_{t} \mid I_{t-1}\right)+\varepsilon_{t},
$$

where the financial returns, $y_{t}=\Delta \log P_{t}$, represent the log-difference in financial commodity or agricultural prices, $P_{t}, I_{t-1}$ is the information set at time $t-1$, and $\varepsilon_{t}$ is a conditionally heteroskedastic error term, or returns shock. In order to derive conditional volatility specifications, it is necessary to specify the stochastic processes underlying the returns shocks, $\varepsilon_{t}$. The most popular univariate conditional volatility model, GARCH model, is discussed below.

Now consider the random coefficient autoregressive process of order one underlying the return shocks, $\varepsilon_{t}$ :

$$
\varepsilon_{t}=\phi_{t} \varepsilon_{t-1}+\eta_{t}
$$

where

$\phi_{t} \sim i i d(0, \alpha), \alpha \geq 0$,

$\eta_{t} \sim \operatorname{iid}(0, \omega), \omega \geq 0$

$\eta_{t}=\varepsilon_{t} / \sqrt{h_{t}}$ is the standardized residual, with $h_{t}$ defined below. 
[21] Tsay (1987) derived the ARCH (1) model of [26] Engle (1982) from equation (2) as:

$$
h_{t} \equiv E\left(\varepsilon_{t}^{2} \mid I_{t-1}\right)=\omega+\alpha \varepsilon_{t-1}^{2}
$$

where $h_{t}$ represents conditional volatility, and $I_{t-1}$ is the information set available at time $t$-1. A lagged dependent variable, $h_{t-1}$, is typically added to equation (3) to improve the sample fit:

$$
h_{t} \equiv E\left(\varepsilon_{t}^{2} \mid I_{t-1}\right)=\omega+\alpha \varepsilon_{t-1}^{2}+\beta h_{t-1}
$$

From the specification of equation (2), it is clear that both $\omega$ and $\alpha$ should be positive as they are the unconditional variances of two different stochastic processes.

Given the non-normality of the returns shocks, the Quasi-Maximum Likelihood Estimators (QMLE) of the parameters have been shown to be consistent and asymptotically normal in several papers. For example, [27] Ling and McAleer (2003) showed that the QMLE for a generalized $\operatorname{ARCH}(p, q)$ (or $\operatorname{GARCH}(p, q)$ ) is consistent if the second moment is finite. A sufficient condition for the QMLE of GARCH(1,1) in equation (4) to be consistent and asymptotically normal is $\alpha+\beta<1$.

In general, the proofs of the asymptotic properties follow from the fact that GARCH can be derived from a random coefficient autoregressive process. [15] McAleer et al. 
(2008) give a general proof of asymptotic normality for multivariate models that are based on proving that the regularity conditions satisfy the conditions given in [32] Jeantheau (1998) for consistency, and the conditions given in Theorem 4.1.3 in [54] Amemiya (1985) for asymptotic normality.

\subsubsection{Multivariate Conditional Volatility}

The multivariate extension of the univariate ARCH and GARCH models is given in [55] Baba et al. (1985) and [25] Engle and Kroner (1995). In order to establish volatility spillovers in a multivariate framework, it is useful to define the multivariate extension of the relationship between the returns shocks and the standardized residuals, that is, $\eta_{t}=\varepsilon_{t} / \sqrt{h_{t}}$. The multivariate extension of equation (1), namely $y_{t}=$ $E\left(y_{t} \mid I_{t-1}\right)+\varepsilon_{t}$, can remain unchanged by assuming that the three components are now $m \times 1$ vectors, where $m$ is the number of financial assets. The multivariate definition of the relationship between $\varepsilon_{t}$ and $\eta_{t}$ is given as:

$$
\varepsilon_{t}=D_{t}^{1 / 2} \eta_{t}
$$

where $D_{t}=\operatorname{diag}\left(h_{1 t}, h_{2 t}, \ldots, h_{m t}\right)$ is a diagonal matrix comprising the univariate conditional volatilities.

Define the conditional covariance matrix of $\varepsilon_{t}$ as $Q_{t}$. As the $m \times 1$ vector, $\eta_{t}$, is assumed to be iid for all $m$ elements, the conditional correlation matrix of $\varepsilon_{t}$, which is 
equivalent to the conditional correlation matrix of $\eta_{t}$, is given by $\Gamma_{t}$. Therefore, the conditional expectation of (5) is defined as:

$$
Q_{t}=D_{t}^{1 / 2} \Gamma_{t} D_{t}^{1 / 2}
$$

Equivalently, the conditional correlation matrix, $\Gamma_{t}$, can be defined as:

$$
\Gamma_{t}=D_{t}^{-1 / 2} Q_{t} D_{t}^{-1 / 2}
$$

Equation (6) is useful if a model of $\Gamma_{t}$ is available for purposes of estimating $Q_{t}$, whereas (7) is useful if a model of $Q_{t}$ is available for purposes of estimating $\Gamma_{t}$.

Equation (6) is convenient for a discussion of volatility spillover effects, while both equations (6) and (7) are instructive for a discussion of asymptotic properties. As the elements of $D_{t}$ are consistent and asymptotically normal, the consistency of $Q_{t}$ in (6) depends on consistent estimation of $\Gamma_{t}$, whereas the consistency of $\Gamma_{t}$ in (7) depends on consistent estimation of $Q_{t}$. As both $Q_{t}$ and $\Gamma_{t}$ are products of matrices, with inverses in (7), neither the QMLE of $Q_{t}$ nor $\Gamma_{t}$ will be asymptotically normal based on the definitions given in equations (6) and (7).

\subsubsection{Diagonal BEKK}


The diagonal BEKK model can be derived from a vector random coefficient autoregressive process of order one, which is the multivariate extension of the univariate process given in equation (2):

$$
\varepsilon_{t}=\Phi_{t} \varepsilon_{t-1}+\eta_{t}
$$

where

$\varepsilon_{t}$ and $\eta_{t}$ are $m \times 1$ vectors,

$\Phi_{t}$ is an $m \times m$ matrix of random coefficients,

$\Phi_{t} \sim \operatorname{iid}(0, A), A$ is positive definite,

$\eta_{t} \sim \operatorname{iid}(0, C), C$ is an $m \times m$ matrix.

Vectorization of a full matrix $A$ to vec $A$ can have dimension as high as $m^{2} \times m^{2}$, whereas vectorization of a symmetric matrix $A$ to vech $A$ can have a smaller dimension of $m(m+1) / 2 \times m(m+1) / 2$.

In a case where $A$ is a diagonal matrix, with $a_{i i}>0$ for all $i=1, \ldots, m$ and $\left|b_{j j}\right|<$ 1 for all $j=1, \ldots, m$, so that $A$ has dimension $m \times m$, [15] McAleer et al. (2008) showed that the multivariate extension of $\operatorname{GARCH}(1,1)$ from equation (8) is given as the diagonal BEKK model, namely:

$$
Q_{t}=C C^{\prime}+A \varepsilon_{t-1} \varepsilon_{t-1}^{\prime} A^{\prime}+B Q_{t-1} B^{\prime},
$$


where $A$ and $B$ are both diagonal matrices, though the last term in equation (9) need not come from an underlying stochastic process. The diagonality of the positive definite matrix $A$ is essential for matrix multiplication as $\varepsilon_{t-1} \varepsilon_{t-1}^{\prime}$ is an $m \times m$ matrix; otherwise equation (9) could not be derived from the vector random coefficient autoregressive process in equation (8).

[15] McAleer et al. (2008) showed that the QMLE of the parameters of the diagonal BEKK model were consistent and asymptotically normal, so that standard statistical inference on testing hypotheses is valid. Moreover, as $Q_{t}$ in (9) can be estimated consistently, $\Gamma_{t}$ in equation (7) can also be estimated consistently.

\subsubsection{Full, Triangular and Hadamard BEKK}

The full BEKK model in [55] Baba et al. (1985) and [25] Engle and Kroner (1995), who do not derive the model from an underlying stochastic process, is presented as:

$$
Q_{t}=C C^{\prime}+A \varepsilon_{t-1} \varepsilon_{t-1}^{\prime} A^{\prime}+B Q_{t-1} B^{\prime}
$$

except that $A$ and $B$ in equation (10) are now both full matrices, rather than the diagonal matrices that were derived in equation (9) using the stochastic process in equation (8). The full BEKK model can be replaced by the triangular or Hadamard (element-by-element multiplication) BEKK models, with similar problems of identification and (lack of) existence. The full, triangular and Hadamard BEKK models 
cannot be derived from any known underlying stochastic processes, which means there are no regularity conditions (except by assumption) for checking the internal consistency of the alternative models, and consequently no valid asymptotic properties of the QMLE of the associated parameters (except by assumption).

Moreover, as the number of parameters in a full BEKK model can be as much as $3 m(m+1) / 2$, the "curse of dimensionality" will be likely to arise, which means that convergence of the estimation algorithm can become problematic and less reliable when there is a large number of parameters to be estimated. As a matter of fact, estimation of the full BEKK can be problematic even when $m$ is as low as 5 financial assets. Such computational difficulties do not arise for the diagonal BEKK model. Convergence of the estimation algorithm is more likely when the number of commodities is less than 4, though this is nevertheless problematic in terms of interpretation. Therefore, in the empirical analysis, in order to investigate volatility spillover effects, the diagonal BEKK model will be estimated.

The Diagonal BEKK model is given as equation (9), where the matrices $A$ and $B$ are given as:

$$
A=\left[\begin{array}{ccc}
a_{11} & \cdots & 0 \\
\vdots & \ddots & \vdots \\
0 & \cdots & a_{m m}
\end{array}\right], B=\left[\begin{array}{ccc}
b_{11} & \cdots & 0 \\
\vdots & \ddots & \vdots \\
0 & \cdots & b_{m m}
\end{array}\right]
$$

The Diagonal BEKK model permits a test of Co-volatility Spillover effects, which is the effect of a shock in commodity $j$ at $t-1$ on the subsequent co-volatility between $j$ and another commodity at $t$. Given the Diagonal BEKK model, as expressed in equations (9) 
and (11), the subsequent co-volatility must be between commodities $j$ and $i$ at time $t$.

This leads to the definition of a Co-volatility Spillover Effect as:

Definition: $\frac{\partial H_{i j, t}}{\partial \varepsilon_{j, t-1}}=a_{i i} \times a_{j j} \times \varepsilon_{i, t-1}, i \neq j$.

As $a_{i i}>0$ for all $i$, a test of the co-volatility spillover effect is given as a test of the null hypothesis:

$H_{0}: a_{i i} a_{j j}=0$,

which is a test of the significance of the estimate of $a_{i i} a_{j j}$ in the following co-volatility spillover effect, as $\varepsilon_{i, t-1} \neq 0$ :

$\frac{\partial H_{i j, t}}{\partial \varepsilon_{j, t-1}}=a_{i i} a_{j j} \varepsilon_{i, t-1}, i \neq j$

If $H_{0}$ is rejected against the alternative hypothesis, $H_{1}: a_{i i} a_{j j} \neq 0$, there is a spillover from the returns shock of commodity $j$ at $t-1$ to the co-volatility between commodities $i$ and $j$ at $t$ that depends only on the returns shock of commodity $i$ at $t-1$. It should be emphasized that the returns shock of commodity $j$ at $t-1$ does not affect the co-volatility spillover of commodity $j$ on the co-volatility between commodities $i$ and $j$ at $t$. Moreover, spillovers can and do vary for each observation $t-1$, so that the empirical results average co-volatility spillovers will be presented, based on the average (or mean) return shocks over the sample period.

This leads to a summary of the inputs, outputs and estimation algorithms to be 
conducted for the empirical analysis.

\section{Summary of Inputs and Outputs}

\section{Outputs}
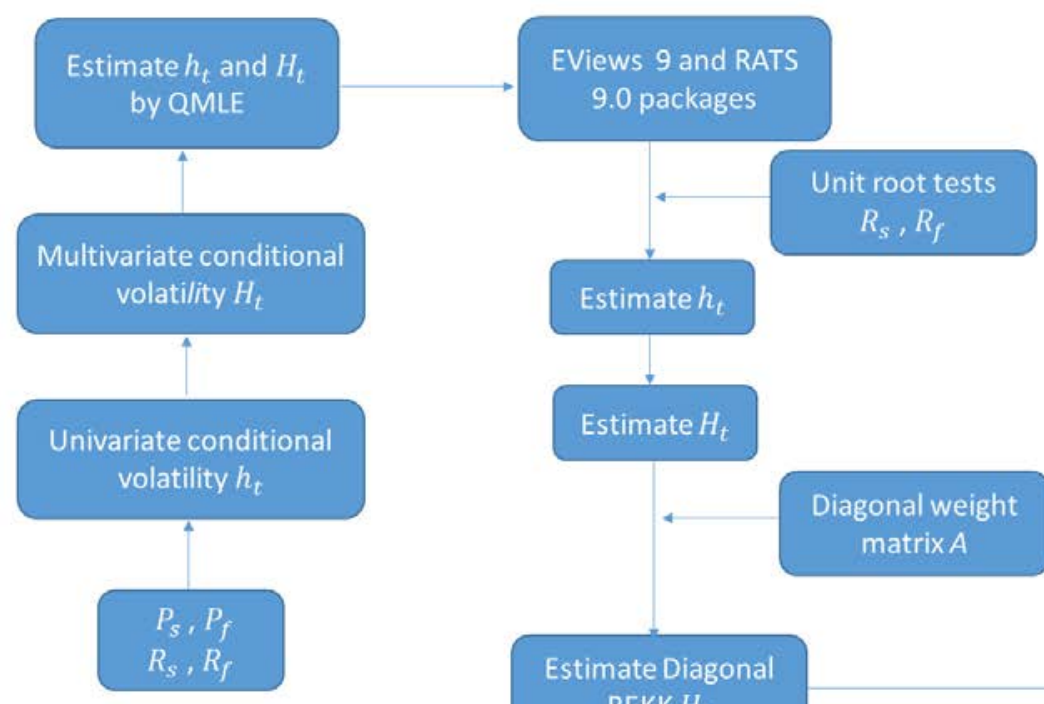

Evaluate $R_{s}, R_{f}$

Evaluate $h_{t}, H_{t}$

Estimate $h_{t}$

Estimate $\frac{\partial H_{i j, t}}{\partial \varepsilon_{j, t-1}}$

Inputs 


\subsection{Data and Variables}

This paper uses daily time series data for the USA on the spot prices and closing futures prices of bio-ethanol and two agricultural commodities, namely corn and sugarcane, in the empirical analysis. The sample covers the period 31 October 2005 to 14 January 2015. The choice of country for the empirical analysis and the length of the sample period was dictated by the availability of data on ethanol spot and futures trading in the USA, which provides the richest source of data to connect the three commodities simultaneously for both spot and futures prices. The USA is the leader in developing a wide range of financial derivatives, such as futures prices, for financial, energy and agricultural commodities. Other agricultural commodities which might be considered as green replacements of gasoline, such as switchgrass, do not have spot and futures data to compare with corn, sugarcane and ethanol.

The data on corn and sugarcane spots are sourced from the United States Department of Agriculture (USDA). The corn spot is corn number 2 yellow (class CORNUS2), and is expressed in US cents per bushel. The sugar spot is raw cane sugar, world (class SUGCNRW), and is expressed in US cents per pound. The bio-ethanol spot is sourced from Thomson Reuters, and is expressed in US dollars per gallon. Data on corn closing futures prices are sourced from Datastream for the US market.

The corn futures class is CC, traded at the Chicago Board of Trade (CBOT), and is expressed in US cents per bushel. Sugar futures is given as sugar \# 11 (class NSB), is 
expressed in US cents per pound, traded at the Coffee, Sugar \& Cocoa Exchange Inc (CSCE). The bio-ethanol futures price is sourced from Thompson Reuters and is expressed in US dollars per gallon. Its class is CZE, and is expressed in US dollars per gallon, traded on eCBOT.

The endogenous variables used in the paper is the daily return rate, where the rate of return is obtained as the natural logarithm of the daily price data, and subtracting the natural logarithms of the daily price data for two consecutive days from each other, and multiplying by 100. $\operatorname{Corn}_{\mathrm{sr}}$, Sugar $\mathrm{sr}$, and Ethanol $\mathrm{sr}_{\text {r }}$ represent the spot returns for corn, sugarcane, and bio-ethanol, and $\operatorname{Corn}_{\mathrm{fr}}, \operatorname{Sugar}_{\mathrm{fr}}$, Ethanol ${ }_{\mathrm{fr}}$ represent the futures returns of corn, sugarcane, and bio-ethanol, respectively. The variable definitions are given in Table 1, according to the spot and futures returns of the three commodities, as well as their transactions markets. The sources of data for the spot and futures prices and returns differ for each of the three commodities. The United States Department of Agriculture (USDA) is the source of data for corn and sugar spot prices, while the Chicago Board of Trade (CBOT) is the source for corn and ethanol futures.

\section{[Insert Table 1 here]}

The descriptive statistics for the endogenous returns of the spot and futures for bio-ethanol and the two agricultural commodities, corn and sugarcane, are given in Table 2. The highest standard deviation for the futures market over the sample period is for bio-ethanol, followed by sugarcane, while the highest standard deviation for the spot 
market over the sample period is for corn.

The returns have different degrees of skewness. Interestingly, virtually all the returns are skewed to the left, indicating that these futures series have longer left tails (extreme losses) than right tails (extreme gains), except for bio-ethanol spot and sugar futures returns, which are skewed to the right. This stylized fact should be of interest to participants in commodity markets. All of the price distributions have kurtosis that is significantly higher than 3 , implying that higher probabilities of extreme market movements in either direction (gains or losses) occur in these futures markets, with greater frequency in practice than would be predicted by the normal distribution. In the spot market, the highest kurtosis is for ethanol spot, followed by sugarcane and corn, while in the futures market, the highest is for sugarcane, followed by bio-ethanol and corn. The Jarque-Bera Lagrange multiplier statistics confirm non-normal distributions in all the return series.

As shown in Figure 5, the volatility of returns for spot and futures of bio-ethanol and the two agricultural commodities display the phenomenon of volatility clustering. Corn and sugar spot returns, and sugar futures returns, display what would be regarded as standard financial returns variations, whereas corn futures returns show an extreme value in 2013. The spot returns for ethanol and highly variable, while ethanol futures returns show substantial variability in 2013-2014. However, the impact of the Global Financial Crisis (GFC) in 2008-09 does not seem to have had a noticeable impact on the volatility of spot and futures returns in the three commodities. 


\section{[Insert Figure 5 and Table 2 here]}

The unit root tests for both endogenous and exogenous variables are summarized in Table 3. The Augmented Dickey-Fuller (ADF) and Phillips-Perron (PP) tests were used to test for unit roots in the individual returns series. The ADF test accommodates serial correlation by specifying explicitly the structure of serial correlation in the errors. The non-parametric PP test allows fairly mild assumptions that do not assume a specific type of serial correlation and heteroskedasticity in the disturbances, and can have higher power than the ADF test under a wide range of circumstances. The null hypothesis of the ADF and PP tests is that the series have a unit root (for further details, see [56] Dickey and Fuller, 1979; [57] Said and Dickey (1984); [58] Phillips and Perron, 1988). In Table 3, based on the ADF and PP test results, the large negative values in all cases indicate rejection of the null hypothesis of unit roots at the $1 \%$ level of significance, Therefore, all the returns series are stationary.

\section{[Insert Table 3 here]}

\section{Results}

\subsection{Testing Co-volatility Spillover Effects}

It is possible to check directly the Co-volatility Spillover effects through testing the significance of the estimates of the matrix $A$ in the Diagonal BEKK model. If 
the null hypothesis $H_{0}$ is rejected, there will be spillovers from the returns shock of commodity $j$ at $t-1$ to the co-volatility between commodities $i$ and $j$ at $t$ that depends only on the returns shock of commodity $i$ at $t-1$.

Tables 4 - 6 show the empirical results of spot markets for the $\operatorname{VAR}(1,1)$ multivariate diagonal $\operatorname{BEKK}(1,1)$ model, and the results of testing the Co-volatility Spillover effects from the significance of the estimates of the matrix $A$ in the Diagonal BEKK model. Estimation of the model in equations (1) and (2) by QMLE are undertaken using both the EViews and RATS econometric software packages for comparison. Table 4 reports the estimates for corn and bio-ethanol, Table 5 reports the results for sugarcane and bio-ethanol, and Table 6 repots the estimates for corn, sugarcane, and ethanol.

\section{[Insert Tables 4-6 here]}

From the estimates of matrix $A$ of the Diagonal BEKK model in Table 4, both coefficients are statistical significant at the $1 \%$ level, which shows spillovers from corn on subsequent bio-ethanol co-volatility with corn, and bio-ethanol on subsequent corn co-volatility with bio-ethanol.

However, Table 5 shows that that not all the estimates in $A$ are significantly different from zero: there is a spillover effect from the returns shock of sugar at $t-1$ to the co-volatility between sugar and ethanol, but no significant effect from the returns shock of ethanol at $t-1$ to the co-volatility between sugar and ethanol. 
If we add three commodities to the Diagonal BEKK model, we can see the empirical results more clearly. As shown in the estimates of the matrix $A$ in Table 6, there are a significant co-volatility spillover effects, particularly corn on subsequent sugarcane co-volatility with corn, and sugarcane on subsequent corn co-volatility with sugarcane.

Tables 7 - 9 show the results of the futures markets for $\operatorname{VAR}(1,1)$ - Diagonal BEKK $(1,1)$ model, and the results of testing the co-volatility spillover effects from the significance of the estimates of $A$ in the Diagonal BEKK model. Table 7 reports the estimates for corn and bio-ethanol, Table 8 reports the results for sugarcane and bio-ethanol, and Table 9 repots the estimates for corn, sugar, and ethanol.

\section{[Insert Tables 7-9 here]}

In Table 7 , both coefficients in $A$ are statistically significant at the $1 \%$ level, which indicates corn on subsequent bio-ethanol co-volatility with corn, and bio-ethanol on subsequent corn co-volatility with bio-ethanol. We also found spillover effects in the futures market of sugarcane and bio-ethanol as the estimates of $A$ in Table 8 show significant effects of sugarcane on subsequent bio-ethanol co-volatility with sugarcane, and bio-ethanol on subsequent sugarcane co-volatility with bio-ethanol.

In Table 9, as we add three commodities into the Diagonal BEKK system, we can see clearly that there are significant co-volatility spillover effects in all 6 cases, namely between corn and sugarcane, corn and ethanol, and sugarcane and ethanol, and the 
reverse.

\subsection{Calculating Co-volatility Spillover Effects}

We use the definition of Co-volatility Spillover Effects in Section 3 to calculate the average Co-volatility Spillover Effects for the three commodities in the spot and futures markets. Table 10 shows the average of the return shocks for three commodities in the spot and futures market, while Table 11 shows the results of average Co-volatility Spillover Effects. From the second row of Table 11, it was found in 2 of 6 cases that there were significant negative co-volatility spillover effects, specifically corn on subsequent sugarcane co-volatility with corn, and sugarcane on subsequent corn co-volatility with sugarcane. In Tables 4-6, for the other 4 cases, no significant co-volatility spillover effects were evident.

\section{[Insert Tables 10-11 here]}

Unlike the case of spot prices, as shown in the third row in Table 11, there are significant positive co-volatility spillover effects in all 6 cases, namely between corn and sugarcane, corn and ethanol, and sugarcane and ethanol, and the reverse. It is clear that the futures prices of bio-ethanol and the two agricultural commodities, corn and sugarcane, have stronger co-volatility spillovers than their spot price counterparts. 


\section{Discussion}

These estimates are reflected in Figures 6-8, which show the unconditional variances of corn, sugarcane and ethanol spot and futures returns, the conditional volatility for corn, sugarcane and ethanol spot and futures returns, and the conditional co-volatility for the pairs corn and sugarcane, corn and ethanol, and sugarcane and ethanol, spot and futures returns. The unconditional variances in Figure 6 are not predicted as they capture the behavior of the data for the whole sample. There are numerous extreme values throughout the sample, especially for corn futures returns, and ethanol spot and futures returns. The conditional volatilities in Figure 7 show persistence and some extreme values, especially for corn futures returns, and ethanol spot and futures returns.

The conditional co-volatilities in Figure 8 are predominantly positive, except for the estimates between corn and ethanol futures returns, and sugarcane and ethanol futures returns. This means that corn and ethanol futures, and sugarcane and ethanol futures, are more useful as suitable hedging instruments, in which negative covariances and correlations are essential for insuring large losses in one financial asset are mitigated by positive returns in the hedging instrument, than are their spot counterparts.

\section{[Insert Figures 6-8 here]}

The Global Financial Crisis (GFC) in 2008-09 does not seem to have had a 
noticeable impact on the unconditional variances of spot and futures returns in the three commodities, except for corn spot returns (Figure 6). Corn spot returns and sugar futures returns show marked peaks during the GFC, but the other four returns do not seem to have been affected by the GFC (Figure 7).

On the other hand, Figure 8 shows that the conditional co-volatilities between corn and sugarcane spot returns and futures are significantly affected by the GFC. This is not of serious concern as these two sets of prices are not likely to be used for hedging purposes. Interestingly, the conditional covariances between corn and ethanol spot returns, and between sugarcane and ethanol spot returns, are not markedly affected by the GFC.

What is of particular interest is that the conditional covariances between corn and ethanol futures returns, and between sugarcane and ethanol futures returns, are significantly affected by the GFC, with high and persistent volatility during this period (Figure 8). This is of some concern as hedging is desirable during serious crises such as the GFC, but it is clear that hedging is difficult during such periods.

One of the primary purposes of the paper was to examine the volatility spillovers for spot and futures returns on bio-ethanol and two related agricultural commodities, namely corn and sugarcane, using the multivariate Diagonal BEKK multivariate conditional volatility model. The daily data used in the empirical analysis were from 31 October 2005 to 14 January 2015, which included the Global Financial Crisis (GFC). The appropriate specification of multivariate conditional volatility models was also discussed, otherwise the empirical results would border on the meaningless, with no 
regularity conditions to sustain the internal consistency of the model, and subsequently no asymptotic properties to enable valid statistical inferences to be made.

For the spot market, it was found that in 2 of 6 cases for the spot and futures returns of the three commodities, there were significant negative co-volatility spillover effects, specifically corn on subsequent sugarcane co-volatility with corn, and sugarcane on subsequent corn co-volatility with sugarcane. These empirical results are indicative of useful hedging strategies. In the other 4 cases for the spot market, there were no significant co-volatility spillover effects.

For futures markets, unlike the case of the spot markets, there were significant positive co-volatility spillover effects in all 6 cases, namely between corn and sugarcane, corn and ethanol, and sugarcane and ethanol, and the reverse pairings. This should be juxtaposed against the estimated negative co-volatilities between corn and ethanol futures returns, and sugarcane and ethanol futures returns (Figure 8).

It is clear that the futures prices and returns of bio-ethanol and the two agricultural commodities, namely corn and sugarcane, have stronger co-volatility spillovers than their spot price counterparts. These results strongly suggest that bio-ethanol and agricultural commodities such as corn and sugarcane should be considered as viable futures products in green energy financial portfolios for optimal risk management and in calculating appropriate hedge ratios.

Future research would ideally incorporate alternative sources of sugar to provide an alternative to gasoline. These agricultural commodities are likely to include switchgrass and kelp. The availability of appropriate financial data in spot and futures 
markets will assist in determining the appropriate prices of alternative agricultural commodities to incorporate into an optimal financial portfolio to mitigate the financial risks associated with renewable and sustainable energy sources, such as ethanol, especially during turbulent periods, such as future global financial crises. 


\section{References}

[1] Popp, J., Z. Lakner, M. Harangi-Rákos, and M. Fári (2014), “The Effect of Bioenergy Expansion: Food, Energy, and Environment”, Renewable and Sustainable Energy Reviews, 32, 559-578. http://dx.doi.org/10.1016/j.rser.2014.01.056).

[2] Popp, J., M. Harangi-Rákos, Z. Gabnai, P. Balogh, G. Antal, and A. Bai (2016), "Biofuels and Their Co-Products as Livestock Feed: Global Economic and Environmental Implications, Molecules, 21(3), 285.

[3] Wisner, R. (2008), "Impact of Ethanol on the Livestock and Poultry Industry, Renewable Fuels Association, October.

(http://www.agmrc.org/renewable_energy/ethanol/impact_of_ethanol_on_the_livestoc k_and_poultry_industry.cfm, accessed 1 January 2016).

[4] Texas Comptroller of Public Accounts (2008), “The Energy Report - Ethanol”. Texas: Texas Comptroller of Public Accounts.

[5] PURE (2015), "European renewable ethanol. Enabling Innovation and Sustainable Development”, State of the Industry, Brussels. Available at:

\section{http://epure.org/media/1215/epure_state_industry2015_web.pdf}

[6] Wisner, R. (2015), “November Monthly Renewable Energy Report. Distillers grains balance sheet”, Agricultural Marketing Resource Center.

[7] RFA (2016), “World fuel ethanol production”, Renewable Fuels Association 2016. Available at: http://ethanolrfa.org/resources/industry/statistics/\#1454098996479_ 8715d404-e546.

[8] Zhang, W., E.A. Yu, S. Rozelle, J. Yang, and S. Msangi (2013), “The Impact of Biofuel Growth on Agriculture: Why is the Range of Estimates so Wide?”, Food Policy, 38, 227-239.

[9] De Gorter, H., D. Drabik, D.R. Just (2013a), "Biofuel Policies and Food Grain Commodity Prices 2006-2012: All Boom and No Bust?”, AgBioForum, 16, 1-13. 
[10] De Gorter, H., D. Drabik, E.M. Kliauga, and G.R. Timilsina (2013b), “An Economic Model of Brazil’s Ethanol-Sugar Markets and Impacts of Fuel Policies”, World Bank, Policy Research Working Paper 6524, June 2013.

[11] Durham, C., G. Davies, T. Bhattacharya (2012), “Can Biofuels Policy Work for Food Security”, UK Department for Environment, Food and Rural Affairs (DEFRA), Contract No.: PB13786.

[12] Engle, R.F. (1982), “Autoregressive Conditional Heteroskedasticity with Estimates of the Variance of United Kingdom Inflation,” Econometrica, 50(4), 987-1007.

[13] Bollerslev, T. (1986), “Generalized Autoregressive Conditional Heteroscedasticity,” Journal of Econometrics, 31(3), 307-327.

[14] Glosten, L.R., R. Jagannathan, and D.E. Runkle (1993), “On the Relation between the Expected Value and Volatility of Nominal Excess Return on Stocks,” Journal of Finance, 48(5), 1779-1801.

[15] McAleer, M., F. Chan, S. Hoti, and O. Lieberman (2008), “Generalized Autoregressive Conditional Correlation,” Econometric Theory, 24(6), 1554-1583.

[16] McAleer, M. (2014), “Asymmetry and Leverage in Conditional Volatility Models,” Econometrics, 2(3), 145-150.

[17] McAleer, M. and C. Hafner (2014), “A One Line Derivation of EGARCH,” Econometrics, 2(2), 92-97.

[18] Martinet, G.G. and M. McAleer (2016), “On the Invertibility of EGARCH( $p, q)$,” to appear in Econometric Reviews.

[19] Nelson, D.B. (1990), “ARCH Models as Diffusion Approximations,” Journal of Econometrics, 45(1-2), 7-38.

[20] Nelson, D.B. (1991), “Conditional Heteroskedasticity in Asset Returns: A New Approach,” Econometrica, 59(2), 347-370.

[21] Tsay, R. S. (1987), “Conditional Heteroscedastic Time Series Models,” Journal of the American Statistical Association, 82(398), 590-604. 
[22] Lence, S.H. and D.J. Hayes (2002), “U.S. Farm Policy and the Volatility of Commodity Prices and Farm Revenues,” American Journal of Agricultural Economics, 84(2), 335-351.

[23] Jin, H.J. and D.L. Frechette (2004), "Fractional Integration in Agricultural Futures Price Volatilities,” American Journal of Agricultural Economics, 86(2), 432-443.

[24] Egelkraut, T.M., P. Garcia, and B.J. Sherrick (2007), “The Term Structure of Implied Forward Volatility: Recovery and Informational Content in the Corn Options Market,” American Journal of Agricultural Economics, 89(1), 1-11.

[25] Engle, R.F. and K.F. Kroner (1995), "Multivariate Simultaneous Generalized ARCH,” Econometric Theory, 11(1), 122-150.

[26] Engle, R.F. (2002), "Dynamic Conditional Correlation: A Simple Class of Multivariate Generalized Autoregressive Conditional Hereoskedasticity Models,” Journal of Business and Economic Statistics, 20(3), 339-350.

[27] Ling, S. and M. McAleer (2003), “Asymptotic Theory for a Vector ARMA-GARCH Model,” Econometric Theory, 19(2), 280-310.

[28] McAleer, M., S. Hoti, and F. Chan (2009), "Structure and Asymptotic Theory for Multivariate Asymmetric Conditional Volatility,” Econometric Reviews, 28, Issue5, 422-440.

[29] Bollerslev, T. (1990), "Modelling the Coherence in Short-run Nominal Exchange Rate: A Multivariate Generalized ARCH Approach,” Review of Economics and Statistics, 72(3), 498-505.

[30] Bollerslev, T., R.F. Engle, and J.M. Wooldridge (1988), “A Capital Asset Pricing Model with Time Varying Covariance,” Journal of Political Economy, 96(1), 116-131.

[31] Hafner, C. and M. McAleer (2014), “A One Line Derivation of DCC: Application of a Vector Random Coefficient Moving Average Process," Tinbergen Institute Discussion Paper, 14-087, The Netherlands.

[32] Jeantheau, T. (1998), "Strong Consistency of Estimators for Multivariate ARCH Models,” Econometric Theory, 14(1), 70-86. 
[33] Tse, Y.K. and A.K.C. Tsui (2002), “A Multivariate GARCH Model with Time-Varying Correlations,” Journal of Business and Economic Statistics, 20(3), 351-362.

[34] Cesar, R.G. and Z. Marco (2012), "Effectiveness of Hedging within the High Price Volatility Context,” Land Economy Working Paper Series, Number 69, SRUC.

[35] Sendhil, R., A. Kar, V.C. Mathur, and G.K. Jha (2013), "Price Discovery, Transmission and Volatility: Evidence from Agricultural Commodity Futures,” Agricultural Economics Research Review, 26(1), 41-54.

[36] Trujillo-Barrera, A., M. Mallory, and P. Garcia (2012), "Volatility Spillovers in U.S. Crude Oil, Ethanol, and Corn Futures Markets,” Journal of Agricultural and Resource Economics, 37(2), 247-262.

[37] Cabrera, B.L. and F. Schulz (2013), "Volatility Linkages between Energy and Agricultural Commodity Prices,” SFB 649 Discussion paper 2013-042, Economic Risk. Berlin.

[38] Chang, C.-L., M. McAleer, and R. Tansuchat (2011), "Crude Oil Hedging Strategies Using Dynamic Multivariate GARCH,” Energy Economics, 33(5), 912-923.

[39] Revoredo-Giha, C. and M. Zuppiroli (2012), "Effectiveness of Hedging within the High Price Volatility Context,” Land Economy Working Paper Series, Number: 69, SRUC.

[40] Chang, C.-L., L.-H. Chen, S. Hammoudeh, and M. McAleer (2012), “Asymmetric Adjustments in the Ethanol and Grains Markets," Energy Economics, 34(6), 1990-2002.

[41] Zhang, Z., L. Lohr, C. Escalante, and M. Wetzstein (2009), "Ethanol, Corn, and Soybean Price Relations in a Volatile Vehicle-fuels Market,” Energies, 2(2), 230-339.

[42] Zhang, D., F. Asche, and A. Oglend (2014), "Ethanol and Trade: An Analysis of Price Transmission in the US Market,” Energy Economics, 42(C), 1-8.

[43] Zhao, J. and B.K. Goodwin (2011), "Volatility Spillovers in Agricultural Commodity Markets: An Application Involving Implied Volatilities from Options 
Markets," Paper to the Agricultural \& Applied Economics Association’s 2011 AAEA \& NAREA Joint Annual Meeting, Pittsburgh, Pennsylvania.

[44] Black, F. (1976), “The Pricing of Commodity Contracts,” Journal of Financial Economics, 3 (1-2), 167-179.

[45] Nazlioglu, S., C. Erdem, and U. Soytas (2013), "Volatility Spillover between Oil and Agricultural Commodity Markets,” Energy Economics, 36, 658-665.

[46] Hafner, C.M. and H. Herwartz (2006), “A Lagrange Multiplier Test for Causality in Variance,” Economics Letters, 93 (1), 137-141.

[47] Chang, C.-L. and M. McAleer (2016), “A Simple Test for Causality in Volatility”, Tinbergen Institute Discussion Paper 2016-094/III, November 2016.

[48] Serra, T. (2011), "Volatility Spillovers between Food and Energy Markets: A Semiparametric Approach,” Energy Economics, 33 (6), 1155-1164.

[49] Serra T. (2012), "Biofuel-related Price Volatility Literature: A Review and New Approaches," Paper Presented at the Conference on International Association of Agricultural Economists (IAAE) Triennial, Foz do Iguaçu, Brazil.

[50] Serra, T., D. Zilberman, and J. Gil (2011), “Price Volatility in Ethanol Markets,” European Review of Agricultural Economics, 38(2), 259-280.

[51] Serra, T. and Gil, J.M. (2013), "Price volatility in food markets: can stock building mitigate price fluctuations," European Review of Agricultural Economics, 40(3), 507-528.

[52] Caporin, M. and M. McAleer (2008), “Scalar BEKK and Indirect DCC,” Journal of Forecasting, 27, Issue 6, 537-549.

[53] Caporin, M. and M. McAleer (2012), “Do We Really Need Both BEKK and DCC? A Tale of Two Multivariate GARCH Models,” Journal of Economic Surveys, 26(4), 736-751.

[54] Amemiya, T. (1985), Advanced Econometrics, Harvard University Press, Cambridge, MA, USA. 
[55] Baba, Y., R.F. Engle, D. Kraft, and K.F. Kroner (1985), “Multivariate Simultaneous Generalized ARCH,” Unpublished manuscript, Department of Economics, University of California, San Diego, CA, USA.

[56] Dickey, D.A. and W.A. Fuller (1979), "Distribution of the Estimators for Autoregressive Time Series with a Unit Root,” Journal of the American Statistical Association, 74(366), 427-431.

[57] Said, S.E. and D.A. Dickey (1984), “Testing for Unit Roots in Autoregressive-Moving Average Models of Unknown Order,” Biometrika, 71 (3), 599-607.

[58] Phillips, P.C.B. and P. Perron (1988), “Testing for a Unit Root in Time Series Regression,” Biometrika, 75(2), 335-346. 
Table 1

Data Sources

\begin{tabular}{cccc}
\hline $\begin{array}{c}\text { Variable } \\
\text { name }\end{array}$ & Definitions & Transaction market & Description \\
\hline Corn $_{\text {sr }}$ & Corn spot & United States Department \\
& return & of Agriculture (USDA) & Corn Number 2 Yellow \\
(US cents per bushel)
\end{tabular}


Table 2

Descriptive Statistics

\begin{tabular}{cccccccc}
\hline Returns & Mean & SD & Max & Min & Skewness & Kurtosis & Jarque-Bera \\
\hline Corn $_{\text {sr }}$ & 0.005 & 1.661 & 10.888 & -12.307 & -0.287 & 4.704 & 8796.03 \\
Corn $_{\text {fr }}$ & 0.005 & 1.581 & 9.801 & -24.528 & -0.643 & 14.858 & 87105.45 \\
Sugar $_{\text {sr }}$ & -0.003 & 2.321 & 20.904 & -20.097 & -0.118 & 5.644 & 10666.35 \\
Sugar $_{\text {fr }}$ & 0.006 & 2.892 & 81.621 & -35.390 & 2.656 & 81.990 & 2644229.19 \\
Ethanol $_{\text {sr }}$ & -0.014 & 3.637 & 94.039 & -79.729 & 2.341 & 290.993 & 8480493.70 \\
Ethanol $_{\text {fr }}$ & -0.027 & 2.178 & 9.403 & -21.566 & -2.115 & 15.951 & 26030.49 \\
\hline
\end{tabular}


Table 3

Unit Root Tests

\begin{tabular}{|c|c|c|c|}
\hline \multirow[b]{2}{*}{ Variables } & \multicolumn{3}{|c|}{ ADF test } \\
\hline & no trend or intercept & intercept & trend and intercept \\
\hline $\operatorname{Corn}_{\text {sr }}$ & $-96.112^{*}$ & $-96.108 *$ & $-96.103^{*}$ \\
\hline $\operatorname{Corn}_{\mathrm{fr}}$ & $-93.266^{*}$ & $-93.261^{*}$ & $-93.257 *$ \\
\hline Sugar $_{\text {sr }}$ & $-93.491^{*}$ & $-93.486^{*}$ & $-66.833^{*}$ \\
\hline Sugar $_{\text {fr }}$ & $-74.394^{*}$ & $-74.391 *$ & $-74.387^{*}$ \\
\hline Ethanol $_{\text {sr }}$ & $-24.679 *$ & $-24.674 *$ & $-24.676^{*}$ \\
\hline \multirow[t]{2}{*}{ Ethanol $_{\text {fr }}$} & $-43.089 *$ & $-43.087^{*}$ & $-43.081 *$ \\
\hline & \multicolumn{3}{|c|}{ PP test } \\
\hline Variables & trend or intercept & intercept & trend and intercept \\
\hline $\operatorname{Corn}_{\text {sr }}$ & $-96.430 *$ & $-96.425 *$ & $-96.420^{*}$ \\
\hline $\operatorname{Corn}_{\mathrm{fr}}$ & $-93.243^{*}$ & $-93.239 *$ & $-93.234 *$ \\
\hline Sugar $_{\text {sr }}$ & $-93.425 *$ & $-93.419 *$ & $-93.175 *$ \\
\hline $\operatorname{Sugar}_{\mathrm{fr}}$ & $-102.251^{*}$ & $-102.247^{*}$ & $-102.241 *$ \\
\hline Ethanol $_{s r}$ & $-49.528 *$ & $-49.518^{*}$ & $-49.517^{*}$ \\
\hline Ethanol $_{\text {fr }}$ & $-43.108 *$ & $-43.104^{*}$ & $-43.098 *$ \\
\hline
\end{tabular}

Note: * denotes the null hypothesis of a unit root is rejected at the $1 \%$ level of significance. 
Table 4

Diagonal BEKK-Spot $\left(\right.$ Corn $\left._{s r}\right)\left(\right.$ Ethanol $\left._{s r}\right)$

\begin{tabular}{lcc}
\hline Mean equation & Corn $_{\text {sr }}$ & Ethanol $_{\text {sr }}$ \\
\cline { 2 - 3 } Corn $_{\text {sr }}(-1)$ & 0.002 & $0.059 *$ \\
& $(0.021)$ & $(0.018)$ \\
Ethanol $_{\text {sr }}(-1)$ & -0.015 & 0.002 \\
& $(0.011)$ & $(0.116)$ \\
C & 0.049 & 0.011 \\
& $(0.039)$ & $(0.053)$ \\
\hline
\end{tabular}

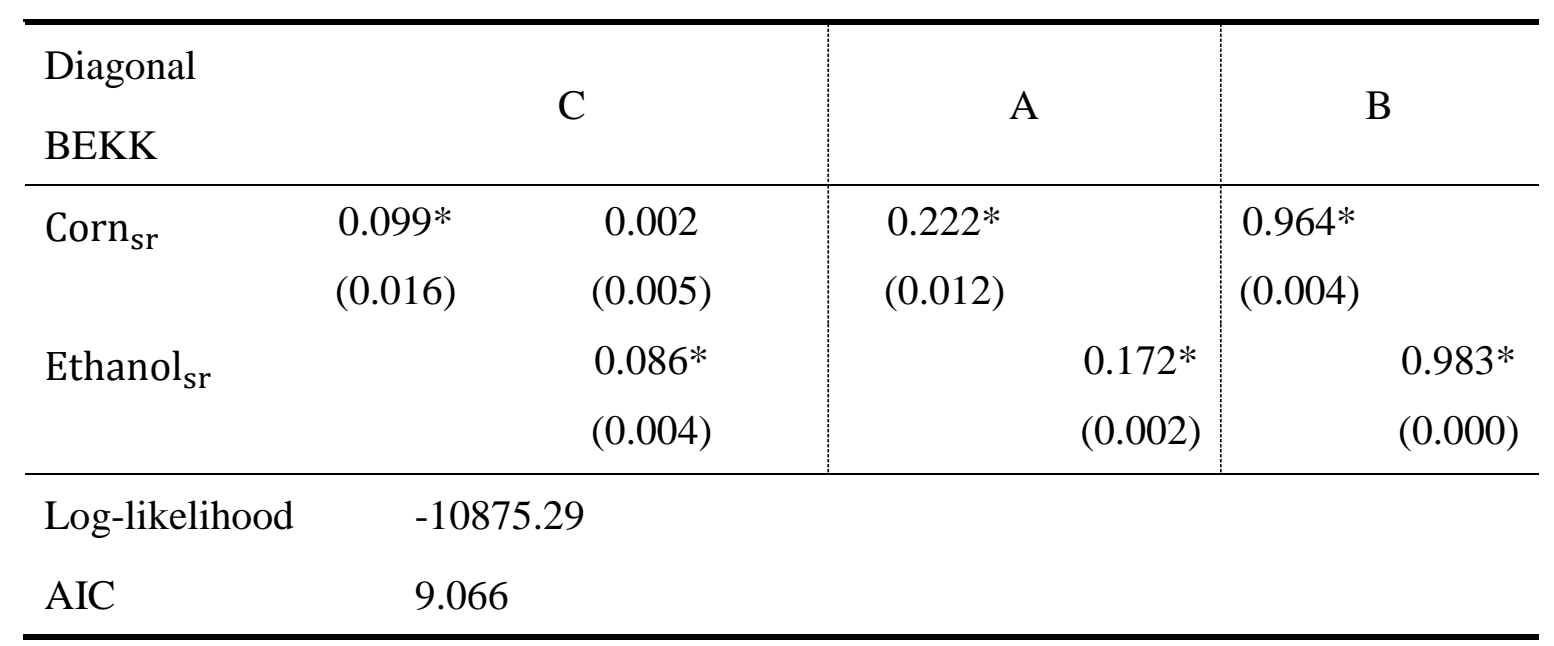

Notes : 1. $\mathrm{A}=\left[\begin{array}{cc}a_{11} & 0 \\ 0 & a_{22}\end{array}\right], \mathrm{B}=\left[\begin{array}{cc}b_{11} & 0 \\ 0 & b_{22}\end{array}\right], \mathrm{C}=\left[\begin{array}{cc}c_{11} & c_{12} \\ 0 & c_{22}\end{array}\right]$

2. Standard errors are in parentheses, * denotes significance level $1 \%$.

3.Substituted Coefficients:

GARCH1 $=0.099+0.049 \times$ RESID1 $(-1)^{2}+0.929 \times$ GARCH1 $(-1)$

GARCH2 $=0.086+0.029 \times$ RESID2 $(-1)^{2}+0.966 \times$ GARCH2 $(-1)$

COV1_2 $=0.002+0.0381 \times$ RESID1 $(-1) \times$ RESID2 $(-1)+0.947 \times$ COV1_2(-1) 
Table 5

Diagonal BEKK-Spot $\left(\right.$ Sugar $\left._{s r}\right)\left(\right.$ Ethanol $\left._{s r}\right)$

\begin{tabular}{lcc}
\hline Mean equation & Sugar $_{\mathrm{sr}}$ & Ethanol $_{\mathrm{sr}}$ \\
\hline Suger $_{\mathrm{sr}}(-1)$ & -0.028 & $0.071^{* * *}$ \\
& $(0.027)$ & $(0.022)$ \\
Ethanol $_{\mathrm{sr}}(-1)$ & $-0.050^{* * *}$ & -0.001 \\
& $(0.020)$ & $(0.362)$ \\
$\mathrm{C}$ & 0.071 & 0.013 \\
& $(0.054)$ & $(0.056)$ \\
\hline
\end{tabular}

\begin{tabular}{|c|c|c|c|c|c|c|}
\hline $\begin{array}{c}\text { Diagonal } \\
\text { BEKK }\end{array}$ & \multicolumn{2}{|c|}{$\mathrm{C}$} & \multicolumn{2}{|c|}{ A } & \multicolumn{2}{|c|}{ B } \\
\hline Sugar $_{\text {sr }}$ & $\begin{array}{c}0.908 * * * \\
(0.018)\end{array}$ & $\begin{array}{c}0.106 \\
(0.102)\end{array}$ & $\begin{array}{c}0.297^{* * *} \\
(0.013)\end{array}$ & & $\begin{array}{c}0.862 * * * \\
(0.004)\end{array}$ & \\
\hline Ethanol $_{\mathrm{sr}}$ & & $\begin{array}{c}2.120^{* * *} \\
(0.009)\end{array}$ & & $\begin{array}{l}-0.001 \\
(0.591)\end{array}$ & & $\begin{array}{c}0.203^{* * *} \\
(0.020)\end{array}$ \\
\hline Log-likelihood & -647 & & & & & \\
\hline AIC & 8.785 & & & & & \\
\hline
\end{tabular}

Notes : 1. $\mathrm{A}=\left[\begin{array}{cc}a_{11} & 0 \\ 0 & a_{22}\end{array}\right], \mathrm{B}=\left[\begin{array}{cc}b_{11} & 0 \\ 0 & b_{22}\end{array}\right], \quad \mathrm{C}=\left[\begin{array}{cc}c_{11} & c_{12} \\ 0 & c_{22}\end{array}\right]$

2. Standard errors are in parentheses, * denotes significance level $1 \%$.

3.Substituted Coefficients:

GARCH1 $=0.908+0.088 \times$ RESID $1(-1)^{2}+0.743 \times$ GARCH1 $(-1)$

GARCH2 $=2.120+0.000 \times$ RESID2 $(-1)^{2}+0.041 \times$ GARCH2 $(-1)$

COV1_2 $=0.106+0.256 \times$ RESID1 $(-1) \times$ RESID2 $(-1)-0.0002 \times$ COV1_2(-1) 
Table 6

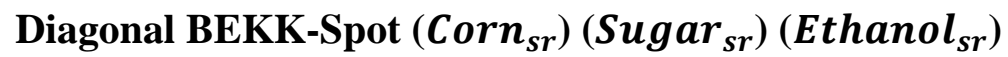

\begin{tabular}{cccc}
\hline Mean equation & Corn $_{\text {sr }}$ & Sugar $_{\text {sr }}$ & Ethanol $_{\text {sr }}$ \\
\hline Corn $_{\text {sr }}(-1)$ & -0.003 & $0.081^{* *}$ & -0.005 \\
Sugar $_{\text {sr }}(-1)$ & $(0.025)$ & $(0.024)$ & $(0.026)$ \\
& 0.007 & $-0.051^{*}$ & $0.073^{*}$ \\
Ethanol $_{\text {sr }}(-1)$ & $(0.022)$ & $(0.025)$ & $(0.023)$ \\
& -0.027 & $-0.051^{*}$ & -0.002 \\
$\mathrm{C}$ & $(0.029)$ & $(0.021)$ & $(0.025)$ \\
& $0.151^{* *}$ & 0.074 & 0.015 \\
& $(0.053)$ & $(0.053)$ & $(0.055)$ \\
\hline
\end{tabular}

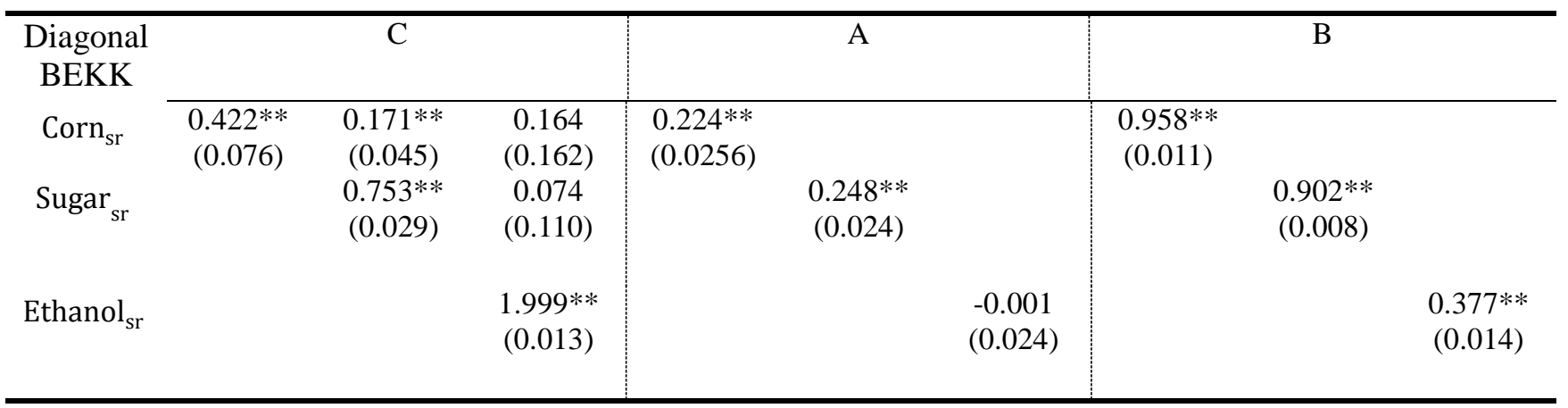

Log-likelihood

$-9736.477$

AIC

13.208

Notes : 1. $\mathrm{A}=\left[\begin{array}{ccc}a_{11} & 0 & 0 \\ 0 & a_{22} & 0 \\ 0 & 0 & a_{33}\end{array}\right], \mathrm{B}=\left[\begin{array}{ccc}b_{11} & 0 & 0 \\ 0 & b_{22} & 0 \\ 0 & 0 & b_{33}\end{array}\right], \mathrm{C}=\left[\begin{array}{ccc}c_{11} & c_{12} & c_{13} \\ 0 & c_{22} & c_{23} \\ 0 & 0 & c_{33}\end{array}\right]$

2.Standard errors are in parentheses, $*$ denotes significance level $5 \%$, ** significance level $1 \%$.

3.Substituted Coefficients:

GARCH1 $=0.422+0.050 \times \operatorname{RESID} 1(-1)^{2}+0.918 \times$ GARCH1 $(-1)$

GARCH2 $=0.753+0.062 \times$ RESID2 $(-1)^{2}+0.814 \times$ GARCH2 $(-1)$

GARCH3 $=1.999+0.000 \times$ RESID3 $(-1)^{2}+0.142 \times$ GARCH3 $(-1)$

COV1_2 $=0.171+0.056 \times$ RESID1 $(-1) \times$ RESID2 $(-1)+0.864 \times$ COV1_2(-1)

COV1_3 $=0.164+0.001 \times$ RESID1 $(-1) \times$ RESID3 $(-1)+0.361 \times$ COV1_3(-1)

COV2_3 $=0.074+0.001 \times$ RESID2(-1) $\times$ RESID3 $(-1)+0.340 \times$ COV2_3(-1) 
Table 7

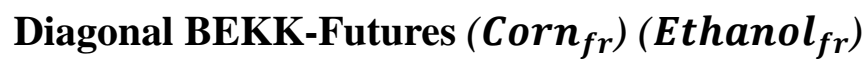

\begin{tabular}{ccc}
\hline Mean equation & Corn $_{\mathrm{fr}}$ & Ethanol $_{\mathrm{fr}}$ \\
\hline $\operatorname{Corn}_{\mathrm{fr}}(-1)$ & 0.006 & 0.022 \\
& $(0.023)$ & $(0.018)$ \\
Ethanol $_{\mathrm{fr}}(-1)$ & $0.048^{*}$ & $0.049 *$ \\
& $(0.019)$ & $(0.022)$ \\
$\mathrm{C}$ & 0.013 & -0.037 \\
& $(0.039)$ & $(0.029)$ \\
\hline
\end{tabular}

\begin{tabular}{|c|c|c|c|c|c|c|}
\hline & \multicolumn{2}{|c|}{$\mathrm{C}$} & \multicolumn{2}{|c|}{ A } & \multicolumn{2}{|c|}{ B } \\
\hline \multirow[t]{2}{*}{$\operatorname{Corn}_{\mathrm{fr}}$} & $0.082 * *$ & $0.044 * *$ & $0.205^{* *}$ & & $0.972 * *$ & \\
\hline & $(0.010)$ & $(0.005)$ & $(0.009)$ & & $(0.002)$ & \\
\hline \multirow[t]{2}{*}{ Ethanol $_{\mathrm{fr}}$} & & $0.038 * *$ & & $0.327^{* *}$ & & $0.951 * *$ \\
\hline & & $(0.007)$ & & $(0.007)$ & & $(0.002)$ \\
\hline Log-likelihood & -918 & & & & & \\
\hline AIC & 8.026 & & & & & \\
\hline
\end{tabular}

Notes : 1. $\mathrm{A}=\left[\begin{array}{cc}a_{11} & 0 \\ 0 & a_{22}\end{array}\right], \mathrm{B}=\left[\begin{array}{cc}b_{11} & 0 \\ 0 & b_{22}\end{array}\right], \mathrm{C}=\left[\begin{array}{cc}c_{11} & c_{12} \\ 0 & c_{22}\end{array}\right]$

2. Standard errors are in parentheses, * denotes significance level 5\%, ** significance level 1\%.

3. Substituted Coefficients:

GARCH1 $=0.082+0.042 \times$ RESID1 $(-1)^{2}+0.945 \times$ GARCH1 $(-1)$

GARCH2 $=0.038+0.107 \times$ RESID2 $(-1)^{2}+0.904 \times$ GARCH2 $(-1)$

COV1_2 $=0.044+0.067 \times$ RESID1 $(-1) \times$ RESID2 $(-1)+0.924 \times$ COV1_2(-1) 
Table 8

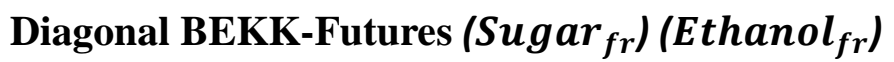

\begin{tabular}{ccc}
\hline Mean equation & Sugar $_{\mathrm{fr}}$ & Ethanol $_{\mathrm{fr}}$ \\
\hline Sugar $_{\mathrm{fr}}(-1)$ & 0.006 & $0.029^{*}$ \\
& $(0.020)$ & $(0.015)$ \\
Ethanol $_{\mathrm{fr}}(-1)$ & 0.017 & $0.051^{* *}$ \\
& $(0.018)$ & $(0.021)$ \\
$\mathrm{C}$ & -0.042 & -0.042 \\
& $(0.038)$ & $(0.036)$ \\
\hline
\end{tabular}

\begin{tabular}{|c|c|c|c|c|c|c|}
\hline \multirow[b]{2}{*}{ Sugar $_{\text {fr }}$} & \multicolumn{2}{|c|}{$\mathrm{C}$} & \multicolumn{2}{|c|}{ A } & \multicolumn{2}{|c|}{ B } \\
\hline & $0.025 * * *$ & 0.004 & $0.199 * * *$ & & $0.978 * * *$ & \\
\hline & $(0.006)$ & (0.005) & $(0.009)$ & & $(0.002)$ & \\
\hline \multirow[t]{2}{*}{ Ethanol $_{\mathrm{fr}}$} & & $0.095 * * *$ & & $0.299 * * *$ & & $0.949 * * *$ \\
\hline & & $(0.012)$ & & $(0.010)$ & & $(0.003)$ \\
\hline
\end{tabular}

Log-likelihood $\quad-9692.554$

AIC $\quad 8.465$

Notes: 1. $\mathrm{A}=\left[\begin{array}{cc}\mathrm{a}_{11} & 0 \\ 0 & \mathrm{a}_{22}\end{array}\right], \mathrm{B}=\left[\begin{array}{cc}\mathrm{b}_{11} & 0 \\ 0 & \mathrm{~b}_{22}\end{array}\right], \mathrm{C}=\left[\begin{array}{cc}\mathrm{c}_{11} & \mathrm{c}_{12} \\ 0 & \mathrm{c}_{22}\end{array}\right]$

2. Standard errors are in parentheses, * significance level $10 \%$, ** significance level $5 \%$, *** significance level $1 \%$.

3. Substituted Coefficients:

GARCH1 $=0.025+0.040 \times$ RESID1 $(-1)^{2}+0.956 \times$ GARCH1 $(-1)$

GARCH2 $=0.095+0.090 \times$ RESID2 $(-1)^{2}+0.900 \times$ GARCH2 $(-1)$

COV1_2 $=0.004+0.060 \times$ RESID1 $(-1) \times$ RESID2 $(-1)+0.928 \times$ COV1_2(-1) 
Table 9

Diagonal BEKK-Futures $\left(\right.$ Corn $\left._{f r}\right)\left(\right.$ Sugar $\left._{f r}\right)\left(\right.$ Ethanol $\left._{f r}\right)$

\begin{tabular}{cccc}
\hline Mean equation & Corn $_{\text {fr }}$ & Sugar $_{\text {fr }}$ & Ethanol $_{\text {fr }}$ \\
\hline Corn $_{\text {fr }}(-1)$ & 0.004 & -0.001 & 0.020 \\
Sugar $_{\text {fr }}(-1)$ & $(0.023)$ & $(0.021)$ & $(0.020)$ \\
& 0.017 & 0.005 & 0.018 \\
Ethanol $_{\text {fr }}(-1)$ & $(0.017)$ & $(0.019)$ & $(0.014)$ \\
& $0.045^{*}$ & 0.014 & $0.047^{*}$ \\
C & $(0.019)$ & $(0.020)$ & $(0.022)$ \\
& 0.011 & -0.035 & -0.035 \\
& $(0.039)$ & $(0.039)$ & $(0.030)$ \\
\hline
\end{tabular}

\begin{tabular}{|c|c|c|c|c|c|c|c|c|c|}
\hline & & $\mathrm{C}$ & & & A & & & B & \\
\hline \multirow[t]{2}{*}{$\operatorname{Corn}_{\text {fr }}$} & $0.080 * *$ & 0.004 & $0.047 * *$ & $0.187^{* *}$ & & & $0.975^{* *}$ & & \\
\hline & $(0.010)$ & $(0.003)$ & $(0.005)$ & $(0.010)$ & & & $(0.002)$ & & \\
\hline \multirow[t]{2}{*}{ Sugar $_{f r}$} & & $0.022^{* *}$ & 0.002 & & $0.176^{* *}$ & & & $0.982^{* *}$ & \\
\hline & & $(0.005)$ & $(0.004)$ & & (0.008) & & & $(0.002)$ & \\
\hline \multirow[t]{2}{*}{ Ethanol $_{\text {fr }}$} & & & $0.045^{* * *}$ & & & $0.323^{* *}$ & & & $0.951^{* *}$ \\
\hline & & & $(0.007)$ & & & $(0.007)$ & & & $(0.002)$ \\
\hline \multicolumn{2}{|c|}{ Log-likelihood } & -14052.30 & & & & & & & \\
\hline \multicolumn{2}{|l|}{ AIC } & 12.278 & & & & & & & \\
\hline
\end{tabular}

Notes: 1. $A=\left[\begin{array}{ccc}\mathrm{a}_{11} & 0 & 0 \\ 0 & \mathrm{a}_{22} & 0 \\ 0 & 0 & \mathrm{a}_{33}\end{array}\right], \mathrm{B}=\left[\begin{array}{ccc}\mathrm{b}_{11} & 0 & 0 \\ 0 & \mathrm{~b}_{22} & 0 \\ 0 & 0 & \mathrm{~b}_{33}\end{array}\right], \mathrm{C}=\left[\begin{array}{ccc}\mathrm{c}_{11} & \mathrm{c}_{12} & \mathrm{c}_{13} \\ 0 & \mathrm{c}_{22} & \mathrm{c}_{23} \\ 0 & 0 & \mathrm{c}_{33}\end{array}\right]$

2. Standard errors are in parentheses, denotes * significance level 5\%, ** significance level 1\%.

3. Substituted Coefficients:

GARCH1 $=0.080+0.035 \times \operatorname{RESID} 1(-1)^{2}+0.951 \times$ GARCH1 $(-1)$

GARCH2 $=0.022+0.031 \times \operatorname{RESID} 2(-1)^{2}+0.965 \times$ GARCH2 $(-1)$

GARCH3 $=0.045+0.104 \times \operatorname{RESID} 3(-1)^{2}+0.904 \times$ GARCH3 $(-1)$

COV1_2 $=0.004+0.033 \times$ RESID1 $(-1) \times$ RESID2 $(-1)+0.958 \times$ COV1_2(-1)

COV1_3 $=0.047+0.060 \times$ RESID1 $(-1) \times$ RESID3 $(-1)+0.927 \times$ COV1_3(-1)

COV2_3 $=0.002+0.057 \times$ RESID2 $(-1) \times$ RESID3 $(-1)+0.934 \times$ COV2_3(-1) 
Table 10

Average Return Shocks

\begin{tabular}{ccc}
\hline Market & Commodities & Average Return Shocks \\
\hline \multirow{3}{*}{ Spot } & Corn & -0.064 \\
& Sugarcane & -0.016 \\
& Ethanol & 0.002 \\
\hline \hline \multirow{3}{*}{ Futures } & Corn & 0.011 \\
& Sugarcane & 0.028 \\
& Ethanol & 0.008 \\
\hline
\end{tabular}


Table 11

\section{Co-volatility Spillovers}

\begin{tabular}{|c|c|c|}
\hline Market & $\left(\frac{\partial \mathrm{H}_{\mathrm{ij}, \mathrm{t}}}{\partial \varepsilon_{\mathrm{j}, \mathrm{t}-1}}\right)$ & Average Co-volatility Spillovers \\
\hline \multirow{6}{*}{ Spot } & $\mathrm{j}=$ corn, $\mathrm{i}=$ sugarcane & $-0.0036(0.224 \times 0.248 \times(-0.064))$ \\
\hline & $\mathrm{j}=$ sugarcane, $\mathrm{i}=$ corn & $-0.0009(0.224 \times 0.248 \times(-0.016))$ \\
\hline & $\mathrm{j}=$ corn, $\mathrm{i}=$ ethanol & 0 \\
\hline & $\mathrm{j}=$ ethanol, $\mathrm{i}=\mathrm{corn}$ & 0 \\
\hline & $\mathrm{j}=$ sugarcane, $\mathrm{i}=$ ethanol & 0 \\
\hline & $\mathrm{j}=$ ethanol, i=sugarcane & 0 \\
\hline \multirow{6}{*}{ Futures } & $\mathrm{j}=$ corn, $\mathrm{i}=$ sugarcane & $0.0009(0.187 \times 0.176 \times 0.028)$ \\
\hline & $\mathrm{j}=$ sugarcane, $\mathrm{i}=$ corn & $0.0004(0.187 \times 0.176 \times 0.011)$ \\
\hline & $\mathrm{j}=$ corn, $\mathrm{i}=$ ethanol & $0.0005(0.187 \times 0.323 \times 0.008)$ \\
\hline & $\mathrm{j}=$ ethanol, $\mathrm{i}=$ corn & $0.0007(0.187 \times 0.323 \times 0.011)$ \\
\hline & $\mathrm{j}=$ sugarcane, $\mathrm{i}=$ ethanol & $0.0005(0.176 \times 0.323 \times 0.008)$ \\
\hline & $\mathrm{j}=$ ethanol, i=sugarcane & $0.0016(0.176 \times 0.323 \times 0.028)$ \\
\hline
\end{tabular}

Note: Co-volatility Spillover $=\frac{\partial \mathrm{H}_{\mathrm{ij}, \mathrm{t}}}{\partial \varepsilon_{\mathrm{j}, \mathrm{t}-1}}=\mathrm{a}_{\mathrm{ii}} \times \mathrm{a}_{\mathrm{jj}} \cdot \varepsilon_{\mathrm{i}, \mathrm{t}-1}$. 
Figure 1

\section{Use of Biomass Energy in USA}

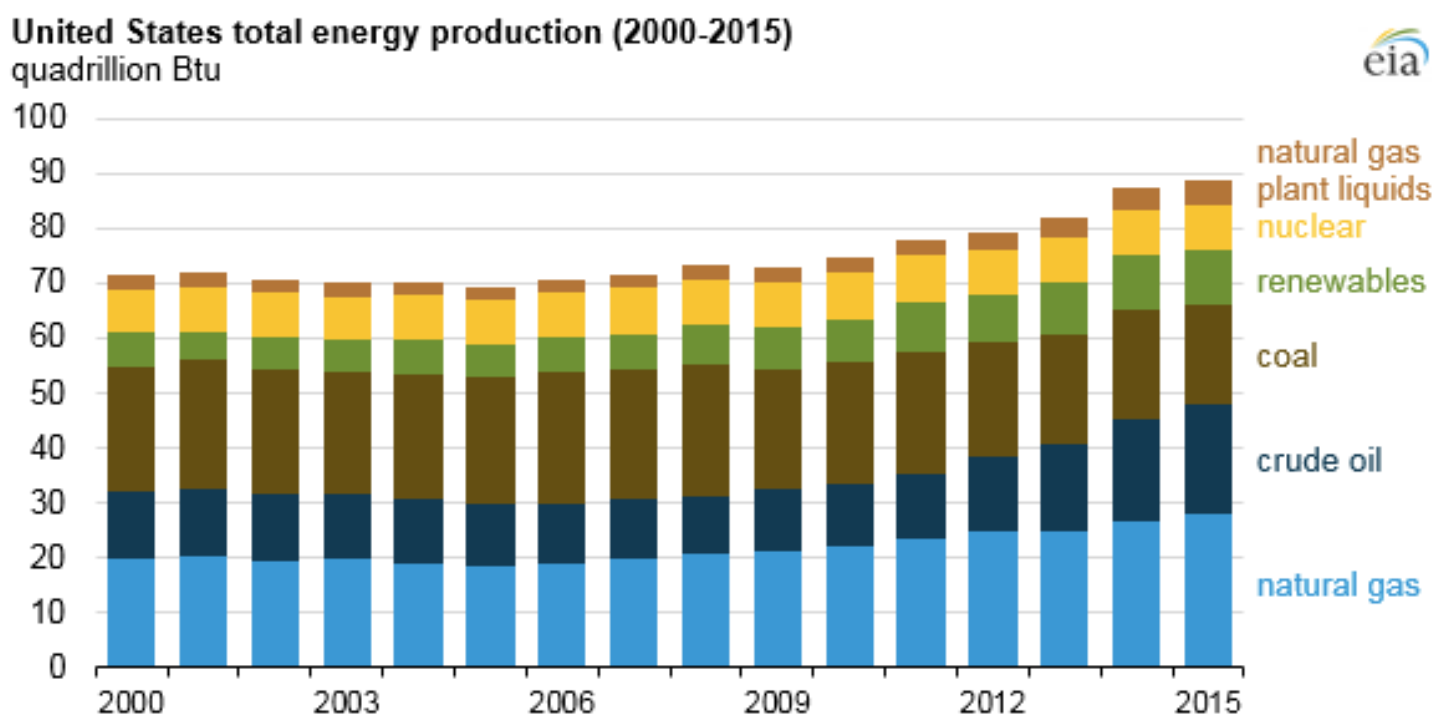

Biomass energy consumed, by type (2002-13) trillion Btu

4,500

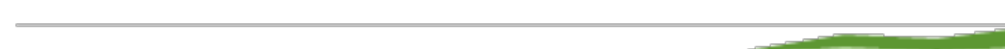

inputs to biodiesel

4,000

3,500

3,000

2,500

2,000

1,500

1,000

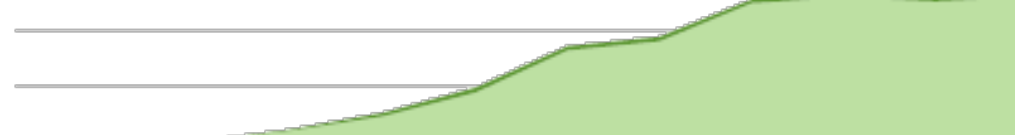

inputs to ethanol

500

0

200220032004200520062007200820092010201120122013

Source: U.S. Energy Information Administration (EIA). 
Figure 2

Bioethanol and Biodiesel

\begin{tabular}{|c|c|c|c|c|c|c|}
\hline & \multicolumn{3}{|c|}{ Bioethanol: mix with gasoline } & \multicolumn{3}{|c|}{ Biodiesel: mix with diesel } \\
\hline & Corn & Sugarcane & $\begin{array}{l}\text { Sugar Beet } \\
\text { (Beetroot) }\end{array}$ & Soybean & Palm oil & Rapeseed \\
\hline $\begin{array}{l}\text { Country } \\
(\%) \\
(2014)\end{array}$ & $\begin{array}{l}30 \\
\% \\
=\text { United States } \\
=\text { China } \\
=\text { Brazil } \\
=\text { Argentina } \\
=\text { Mexico } \\
=\text { other }\end{array}$ & 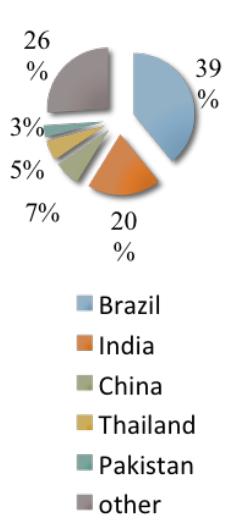 & 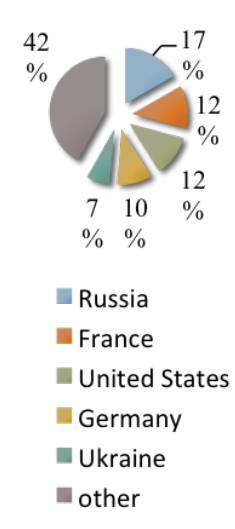 & $\begin{array}{l}\quad 27 \\
\% \\
=\text { United States } \\
=\text { Brazil } \\
=\text { Argentina } \\
\text { = Republic of China } \\
=\text { India } \\
\text { = other }\end{array}$ & 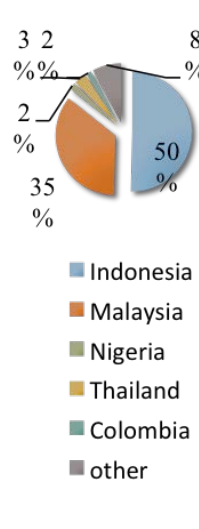 & 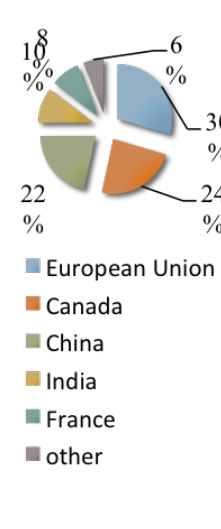 \\
\hline $\begin{array}{l}\text { Production } \\
\text { (One } \\
\text { hundred } \\
\text { million) } \\
\text { (2014) }\end{array}$ & $\begin{array}{l}\text { USA: } 361 \\
\text { China: } 216 \\
\text { Brazil: } 80 \\
\text { World: } 1037\end{array}$ & $\begin{array}{l}\text { Brazil: } 739 \\
\text { India: } 341 \\
\text { China: } 126 \\
\text { World: } 1884\end{array}$ & $\begin{array}{l}\text { France: } 37 \\
\text { Russia: } 33 \\
\text { USA: } 28 \\
\text { World: } 269\end{array}$ & $\begin{array}{l}\text { USA: } 107 \\
\text { Brazil: } 86 \\
\text { Argentina: } \\
54 \\
\text { World: } 306\end{array}$ & $\begin{array}{l}\text { Indonesia: } \\
29 \\
\text { Malaysia: } \\
20 \\
\text { Nigeria: } 1 \\
\text { World: } 57\end{array}$ & $\begin{array}{l}\text { EU: } 24 \\
\text { Canada: } 16 \\
\text { China: } 15 \\
\text { World: } 73\end{array}$ \\
\hline
\end{tabular}

Source: Food and Agriculture Organization of the United Nations (FAO), 2014:

http://www.fao.org/faostat/en/\#home 
Figure 3

Percentage of U.S. Corn Crop Consumed by Ethanol Production and Corn Price per Bushel, 1980-2012

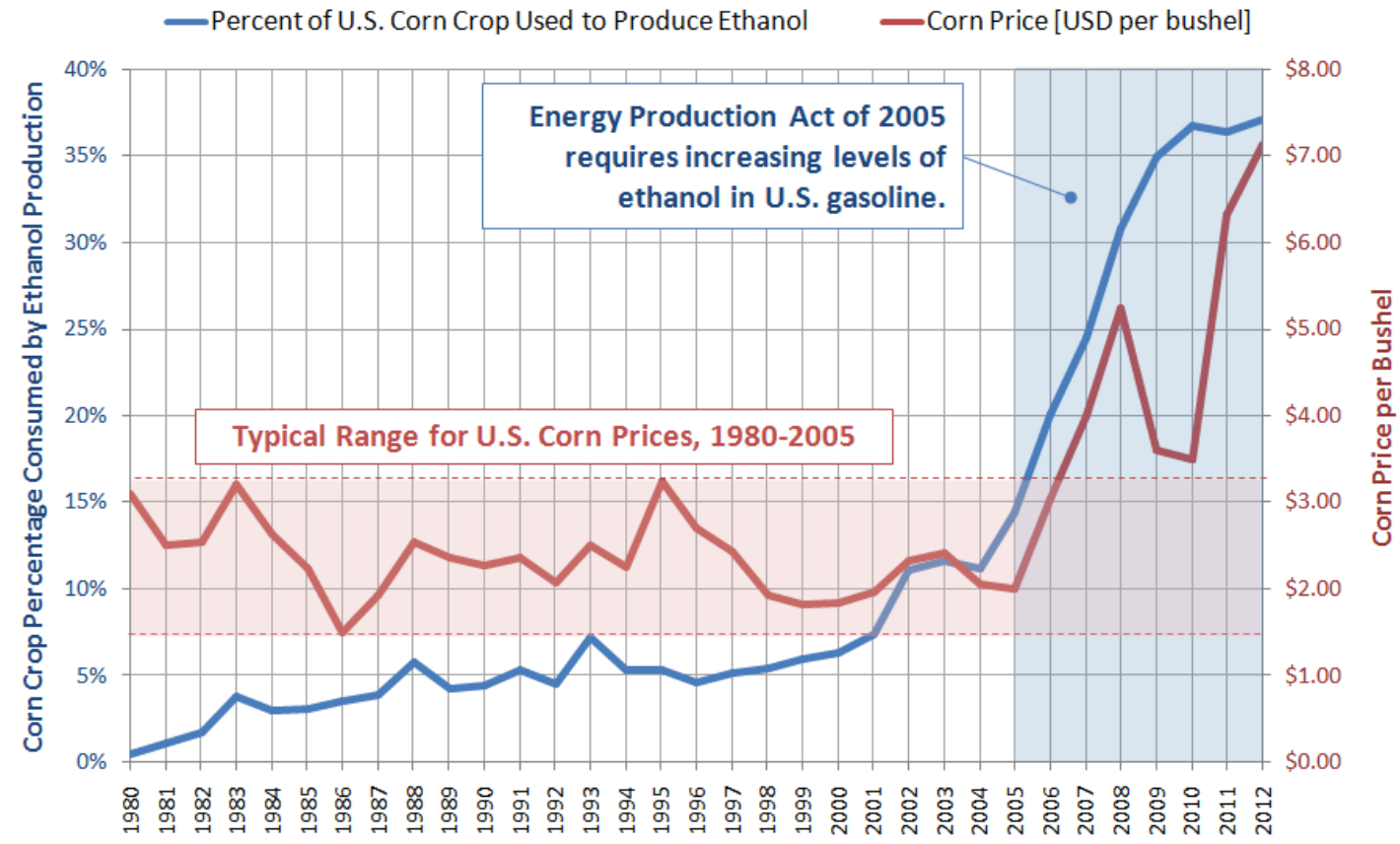

Source: Iowa State University Agricultural Marketing Resource Center, Ethanol Usage Projections \& Corn Balance Sheet and U.S.D.A. Agricultural Prices

Source: United States Department of Agriculture (USDA) and U.S. Energy Information Administration (EIA). 
Figure 4

Historical Prices of Corn and Sugarcane

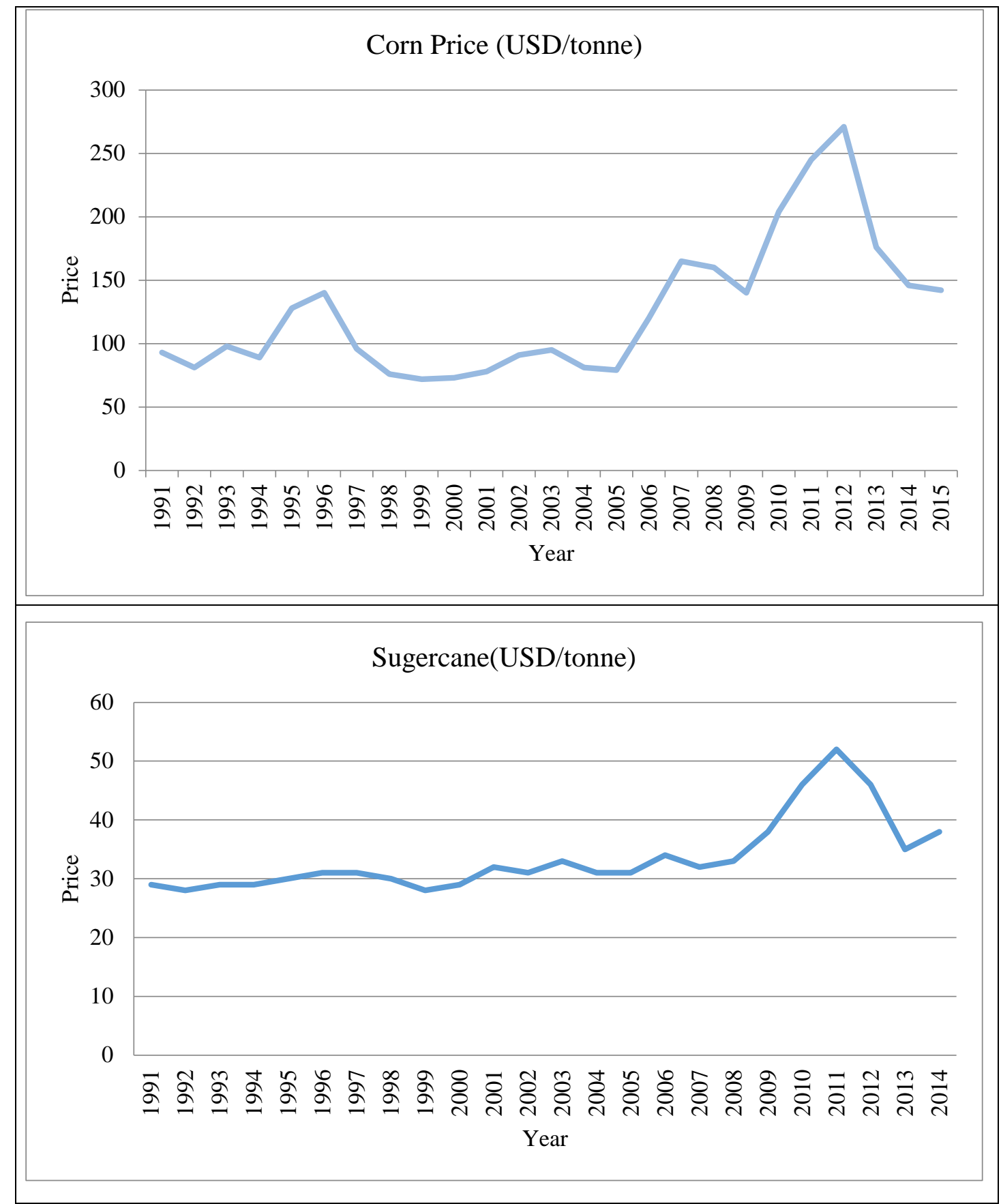

Source: FAO STAT. 
Figure 5

Corn, Sugarcane \& Ethanol Spot and Futures Returns

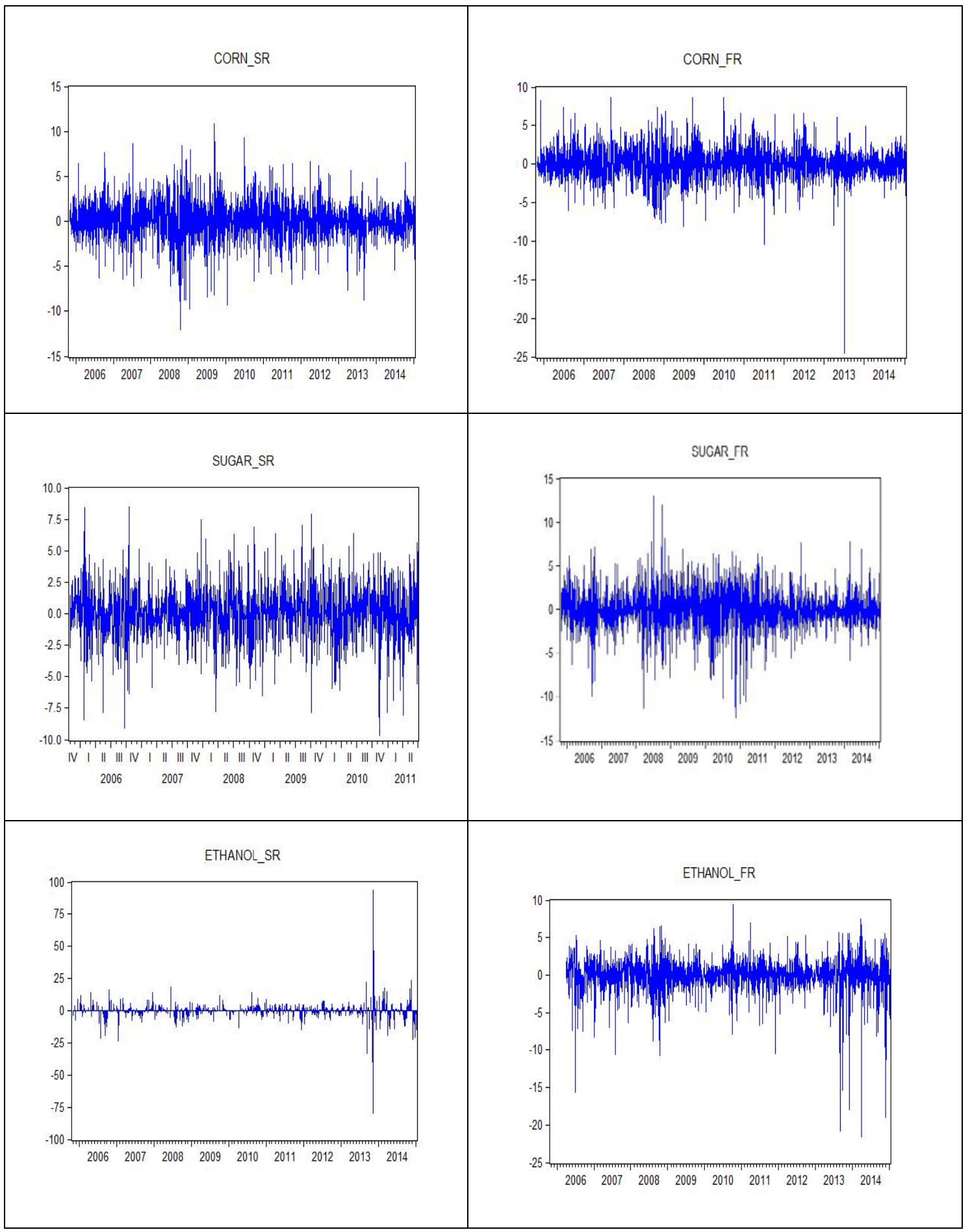


Figure 6

Unconditional Variance of Corn, Sugarcane \& Ethanol Spot and Futures Returns

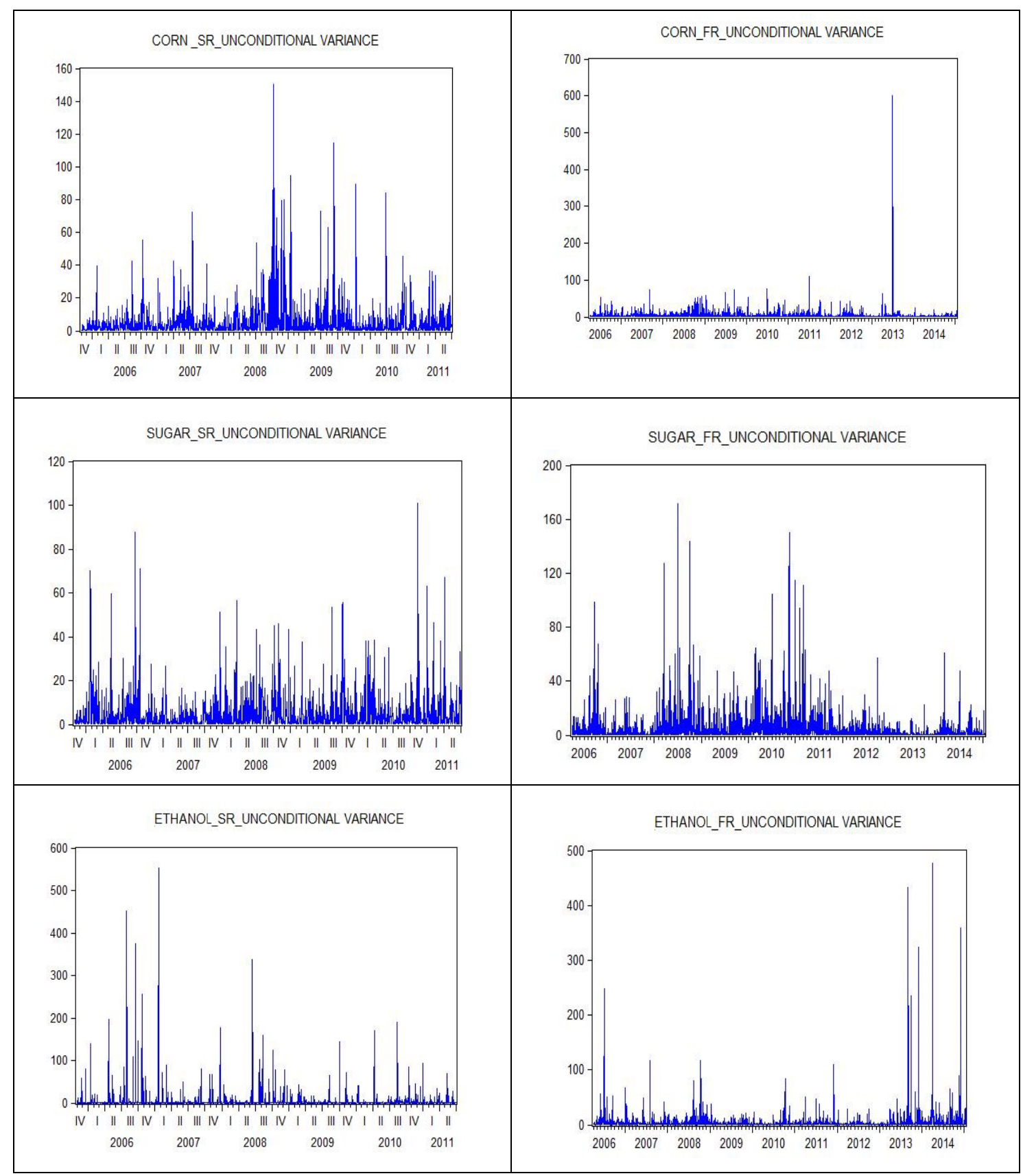


Figure 7

Conditional Volatility for Corn, Sugarcane \& Ethanol Spot and Futures Returns

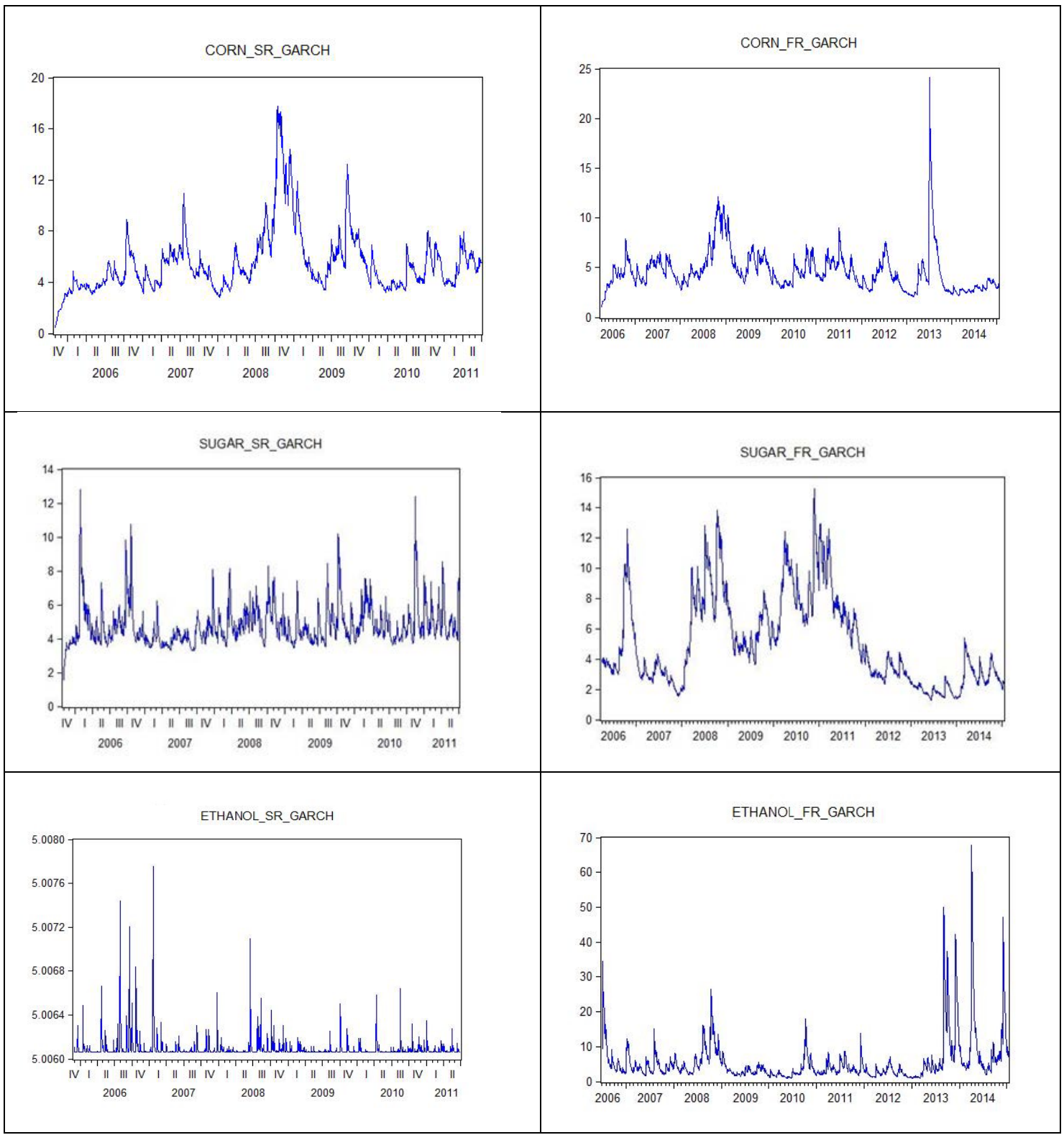


Figure 8

Conditional Co-Volatility for Corn \& Sugarcane, Corn \& Ethanol Sugarcane, \& Ethanol Spot and Futures Returns

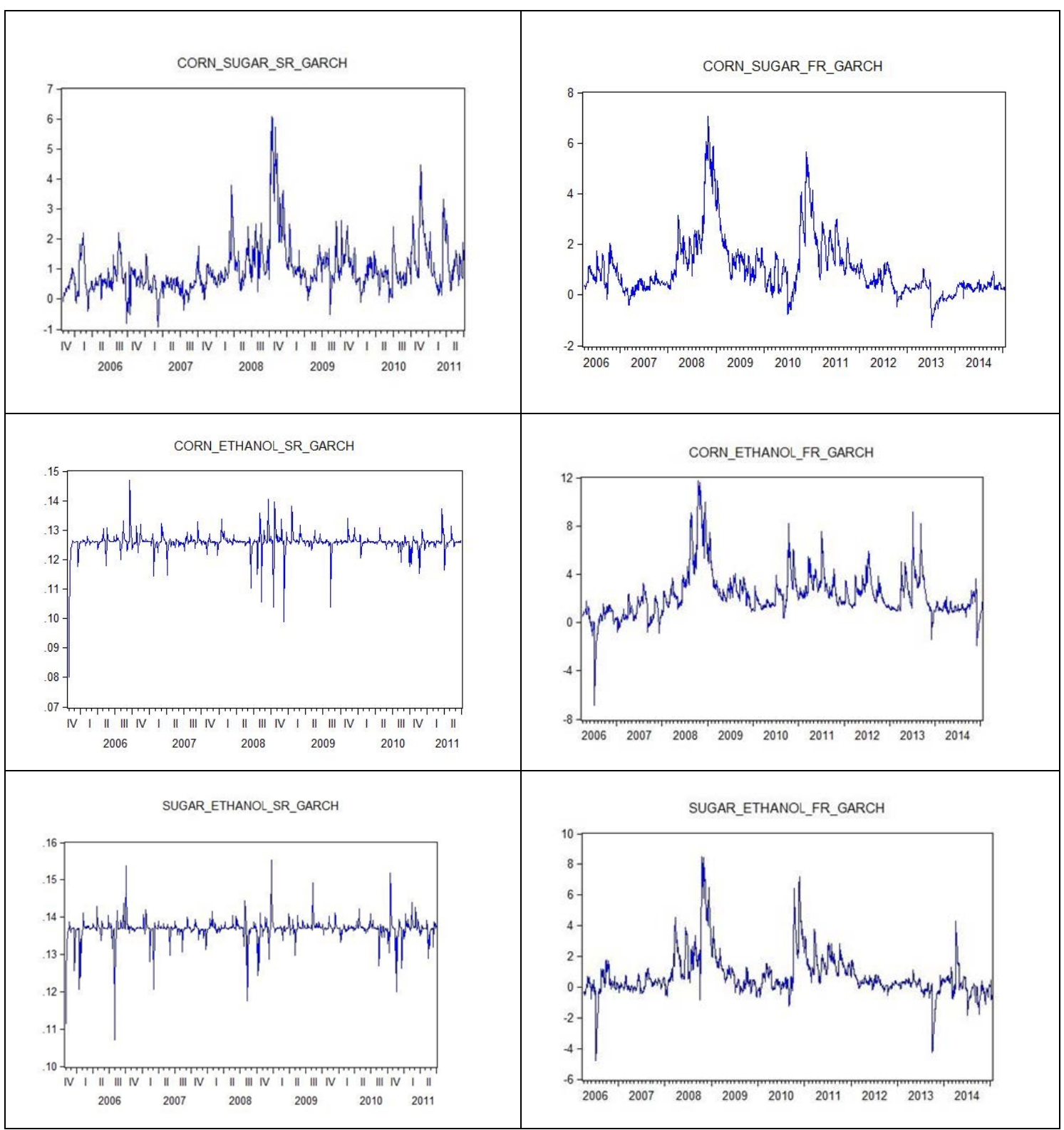

